\title{
Üniversite Öğrencilerinin Yoksulluk Algısı Üzerine Nitel Bir Araştırma*
}

\author{
A Qualitative Research on the Poverty Perception of University Students
}

\author{
Nazmiye KETE TEPE \\ Dr. Ö̆gr. Üyesi., Afyon Kocatepe Üniversitesi, \\ Afyon MYO,nktepe@aku.edu.tr \\ https://orcid.org/0000-0002-8652-0327 \\ Yavuz ÖZER \\ Dr. Öğr. Üyesi., Afyon Kocatepe Üniversitesi, \\ Güzel Sanatlar Fakültesi, Sinema ve Televizyon Bölümü, \\ yavuz.ozer2010@hotmail.com \\ https://orcid.org//0000-0002-0614-7631
}

Makale Başvuru Tarihi: 07.03.2020

Makale Kabul Tarihi: 10.05.2020

Makale Türü: Araştırma Makalesi

\section{ÖZET}

\begin{abstract}
Anahtar
Kelimeler:

Gençlik

Çalışmaları,

Yoksulluk Algısı,

Yoksulluk

Deneyimi,

Öğrenci

Yoksulluğu, nasıl algılandığı ve yaşantılandığı konusu üzerinde pek durulmamaktadır. Yoksullukla mücadelede, yoksul kesimlerin farkındalıklarının artırılması ve geliştirilecek politikalarda onlara söz hakkının tanınmasının önemi göz ardı edilmektedir. Yoksul kesimler tarafindan bir kisırdöngü olarak deneyimlenen yoksulluğa insan hakları açısından yaklaşılması ve yoksulluk olgusunun bir eşitsizlik olarak tanınması önemlidir. Ayrıca dezavantajlı grupların sosyal ve kültürel sermayelerinin artırllması için özel bir çaba gösterilmesi yoksulluğun üstesinden gelmede bir strateji olarak kullanılabilir. Çalışma yoksulluğa iktisadi bir yaklaşımdan çok toplumsal ve kültürel açılardan yaklaşmaktadır. Bu nedenle nitel araştırma yönteminin daha uygun olduğu düşünülerek Afyon Kocatepe Üniversitesi’nin çeşitli fakültelerinde okuyan (70 öğrenci) ve Afyon Meslek Yüksekokulunun farklı programlarında okuyan (30 öğrenci) toplam 100 öğrenciyle derinlemesine görüşmeler gerçekleştirilmiştir. Üniversite ögrencileri için yoksulluk ne anlama gelmektedir? Öğrenciler ne tür yoksunluklar yaşamaktadırlar? Üniversite öğrencileri yaşam koşulları hakkında (durumlarını doğal bulma, kabullenme, kaderci bakış açısı geliştirme, hak temelli bir yaklaşım içinde olma, vb) ne düşünmektedirler? Yaşam koşullarına ilişkin edilgen bir tutum içindeler mi yoksa eleştirel bir düşünme, duruş ya da mücadele yollarını tercih etmekte midirler? Öğrencilerin, ögrenci yoksulluğuna dair çözüm önerileri nelerdir? Öğrencilerin görüşlerine dayanarak bu soruların yanıtları ortaya konmuştur. Araştırma bulguları gençlik ve eğitim politikaları oluşturmada değerlendirilebilecek nitelik taşımaktadır.
\end{abstract}

Yoksulluk olgusu ekonomik krizlerle birlikte uluslararası ve ulusal düzeyde çok fazla dillendirilse de genellikle yoksulluğun ölçülmesi gibi iktisadi yönleri üzerinde odaklanılmakta, konunun yoksullar tarafindan

\section{ABSTRACT}

Although the case of poverty is mentioned at the international and national levels during economic crises, it is generally focused on economic aspects like measuring poverty and how poverty is perceived and

Keywords: experienced by the poor is mostly neglected. The importance of increasing the awareness of the poor and giving them the right to have word on the politics to be developed is neglected. It is important to approach poverty experienced as a vicious circle by the poor, in terms of human rights and to recognize the phenomenon of poverty as an inequality. In addition, making a special effort to increase the social and cultural capital of disadvantaged groups can be used as a strategy to overcome povery. The study approaches poverty from the social and cultural aspects rather than an economic approach. For this purpose, 100 students, those at different faculties of Afyon Kocatepe University (70 students) and those at different programs of Afyon Vocational School (30 students), were interviewed deeply in total. What does poverty mean for university students? What kind of poverties do students experience? What do university students think about their life conditions (considering their condition normal, accepting, developing a fatalistic perspective, being in an approach on the basis of rights, etc.)? Are they in a passivist attitude regarding their living conditions or do they prefer critical thinking, stance or the struggling ways? What are the students' solution suggestions about students' poverty? To answers to these questions are given based on the students' views. The research findings have the characteristic to be evaluated in forming politics on youth and education.

Students'

Poverty, 


\section{GIRISS}

İçinde bulunduğumuz 21. yüzyılda hızlı teknolojik gelişmelerin de etkisiyle ekonomik, toplumsal, siyasal ve kültürel anlamda büyük değişim ve dönüşümler yaşanmaktadır. Gençlik ve eğitim politikalarını oluştururken toplumsal sorunlardan biri olan yoksulluk olgusunu eğitimle birlikte düşünmek gerekmektedir. Böylelikle yoksulluğun eğtim üzerindeki olumsuz etkisini azaltabilecek teorik ve kavramsal tartışmalar ışığında pratiğe dönük kazanımlar elde edilebilir.

$\mathrm{Bu}$ çalışmada, Afyon Kocatepe Üniversitesi örneğinde, üniversite öğrencilerinin yoksulluk deneyimleri ve algıları analiz edilerek gençlik araştırmalarına bir katkı sağlamak hedeflenmiştir. Bu amaçla, söz konusu üniversitenin farklı fakülte ve meslek yüksekokullarında okuyan, rastgele örneklem yoluyla seçilen, toplam 100 öğrenciyle yüzyüze görüşme tasarlanmıştır. Bu görüşmeler; sınıflarda, kampüste ya da öğrenci evlerinde gerçekleştirilmiştir.

Çalışmanın amacı; üniversite öğrencilerinin yoksulluk algısını analiz etmek yani yoksulluk deneyimleri, yoksulluğa bakışları, bu konudaki duygu ve düşüncelerini öğrenmektir. Bu bilgi neden önemlidir? Toplumsal kesimlerin yoksulluğu farklı biçimlerde deneyimlemelerinden hareketle yoksulluk gibi çok boyutlu bir olgunun pratikte uygulanabilir çözümlerine ulaşabilmek için o kesimlerin duygu ve düşünce dünyasını anlamak büyük önem taşımaktadır. $\mathrm{Bu}$ araştırmada öğrencilerin yoksulluk deneyimleri ve algıları nitel yöntemle ortaya konulmaya çalışılmaktadır.

Niteliksel araştırmacılar anlamla ve yaşantıyla yani insanların dünyayı nasıl anlamlandırdıkları ve yaşantıladıklarıyla ilgilenmektedirler. Niteliksel araştırmada ortaya çıkan bilgi genellikle tasvirler ve açıklamalar halindedir. Böylece toplum içinde açıklamaları önemsenmeyen ya da toplum dışına itilenlerin sesleri işitilebilir. Bu sesleri doğrudan duyurmak, bu tür araştırmanın hedeflerinden biridir (Arkonaç, 2014:26).

$\mathrm{Bu}$ çalışmada da üniversite öğrencilerinin yoksulluğa ilişkin seslerine yer verilmiş, elde edilen bilgiler tasvirler ve açıklamalar şeklinde sunulmuştur. Öğrencilerin yoksulluk algıları, deneyimleri ve yoksulluktan nasıl etkilendiklerini anlamaya çalıştığımız bu araştırmayla öğrenci yoksulluğunun bir sorun olarak ortaya konması ve çözüm üretilmesi noktasında dikkate değer bulgulara ulaşıldığı söylenebilir.

Jean Robert ve Macit Rahnema'nın “Yoksulların Gücü” adını taşıyan çalışmaları yoksulluk olgusuna dair başta ekonomik yaklaşım olmak üzere yerleşik düşünme biçimlerini eleştirmektedir. Çalışmanın temel vurgusu, güvensizlik ve yoksulluğu çeşitli biçimlerde yaşayan insanları ilgilendiren ciddi sorunları anlamak için çaba göstermek gerektiği ve bu sorunlara çözümlerin bizzat yoksulların kendileri tarafindan bulunabileceğidir (Robert ve Rahnema, 2011:22).

Çalışmanın kuramsal dayanağı Amartya Sen'in kapasite yaklaşımıdır. Kapasite yaklaşımının önemi; yoksulluğun çok yönlülüğ̈̈nü dikkate alan, bireysel farklılıkları göz önünde tutan, yoksulluğa ekonomik açıdan bakmakla yetinmeyip sosyal ve kültürel açıdan da yaklaşan bir teori olmasından kaynaklanmaktadır. Ayrıca üniversiteler öğretim kurumları olmaları nedeniyle öğrencilerin kapasitelerini arttırma özelliğini de ihtiva etmektedirler. Dezavantajlı yoksul öğrencilerin kapasitelerini arttırmada ne tür politikaların tasarlanabileceğine dair fikirlerin geliştirilmesinde ve uygulanmasında böyle bir çalışmanın başlangıç için önemli olduğu söylenebilir. Yoksulluk bireyde varoluşsal, psikolojik, sosyal-psikolojik düzeyde örneğin bireyin öğrenmesinden, hayata katılımına, umut-umutsuzluk düzeyinden geleceğe yönelik amaçlılık ve kararlılığına dek etkileri olan bir olgudur. Kurum olarak üniversitelerin varoluş amaçlarını ve geleceğe dönük plan ve programlarını gerçekleştirirken yoksulluk olgusunu göz önünde bulundurmaları gerekmektedir. Böylece elde ettikleri sonuçlarda olumlu anlamda niteliksel bir değişim ve dönüşümün sağlanabileceği düşünülmektedir.

\section{KURAMSAL VE KAVRAMSAL ÇERÇEVE}

Farklı yoksulluk tanımları, yoksulluğa dair düşünüş, algılayış biçimleri olarak değerlendirilebilir. İncelenen yoksul kesimlerin özelliklerine ve yoksullukla mücadele stratejilerindeki işlevselliğine göre bir yoksulluk tanımlamasının tercih edilmesi önem taşımaktadır. Bu nedenle bu çalışmada mutlak yoksulluk ve göreli yoksulluk tanımlamaları da ihmal edilmemekle birlikte özellikle Amartya Sen'in kapasite yaklaşımı esas alınmaktadır.

$\mathrm{Bu}$ yaklaşımda yoksulluk, standart yoksulluk ölçütü olan gelir azlığı ölçütünden çok temel kapasitelerden yoksunluk olarak ele alınmaktadır (Sen, 2004:126-127). Bir diğer ifadeyle yoksulluk tüketim maddelerinden 
çok kapasitelere gore tanımlanmaktadır. Kapasite yaklaşımı, yaşam standardı düşüncesine yakındır. Yoksulluğu metalara sahiplik açısından tanımlamak doğru bir bakış açısı değildir. Çünkü böyle bir yaklaşım bireyin söz konusu meta ile ne yapabileceği hakkında fikir vermemektedir. Örneğin, sağlıklı bir bireyle, engelli bir diğer bireyin birer bisiklete sahip olduğunu düşünelim. Engelli birey, bisikleti kullanamıyorsa, bisikletin bu iki bireyin yaşam standardına katkısını aynı şekilde değerlendiremeyiz. Bu örnekte Sen'in dikkat etmemizi istediği şey şudur: yaşam standardını oluşturan unsur meta ya da metanın sahip olduğu özellikleri değil, o metayı ya da özelliklerini kullanarak bir şeyler yapabilmektir (Sen, 1983'ten akt.: Metin, 2014:6317).

İnsani kapasitelerin kullanılabilmesi bireyin hayatına ilişkin kararlar alma ve uygulama gücü kazandırması ve toplumsal hayata katılımını kolaylaştırması bakımından önem taşımaktadır. Kapasite yaklaşımının bir diğer önemi; bireysel özelliklerin, avantaj ve dezavantajların dikkate alınmasını sağlayarak, yoksulluğun çok yönlü ele alınmasıyla birlikte bireysel olan koşulların da gözden kaçmasını engelleyebilmesidir (Kete, 2009:111-112). Amartya Sen'in kapasite yaklaşımı insani gelişme ve insani yoksulluk kavramlarının temelini oluşturması bakımından da önem taşımaktadır.

Birleşmiş Milletler Kalkınma Programı (UNDP) tarafından 1997 yılında İnsani Gelişme Raporu yayımlanmıştır. $\mathrm{Bu}$ raporda insani yoksulluk kavramı geliştirilmiştir. İnsani yoksulluk, insanca yaşam için parasal olanakların yanı sıra temel gereksinimlerin karşılanabilmesinin iktisadi, sosyal ve kültürel bazı olanaklara sahip olmaya bağlı olduğu anlayışına dayanmaktadır (UNDP, 1997'den akt.: Sam, 2008:60). "Rapor, yoksulluğu, kabul edilebilir bir yaşam sürmek için gerekli firsatlardan ve tercihlerden yoksunluk olarak ele almaktadır" (UNDP, 1997'den akt: Metin, 2014:6319).

Sen'in kapasite yaklaşımı, insanın yaşamını, insanın yapmaya ve olmaya değer verdiği şeylerin (işlevlerin) tümü olarak açıklamaktadır. Sen'e gore, bir insanın kapasitesi, o insanın farklı yaşam biçimleri arasında tercihte bulunabilme özgürlüğüne imkân tanımaktadır. Buna gore, insan yaşamının kalitesi de kapasitelerin işlevlere dönüşmesiyle ilgilidir. Sen'in bu düşüncelerinin kökleri Adam Smith, Karl Marx ve Aristoteles'te bulunabilir. Yaşamı, insanın yapmaya ve olmaya değer verdiği işlevler olarak tanımlamak, işlevler hakkında bir değerlendirmeyi gerekli kılmaktadır. Bu değerlendirme ise sadece insanın gelirine ya da alım gücüne dayanarak yapılamaz. Bu işlevler; hastalık ve ölümlerden kaçınma ve yeterli beslenmeden, utanç duymadan var olabilme ve toplumsal yaşama katılabilmeye kadar çeşitlilik göstermektedir (Sen, 1989:43).

Amartya Sen'in özgürlük olarak kavramsallaştırdiği kalkınma kavramı kapasite yaklaşımını anlamak için yararlı olabilir. Ona gore; kalkınma insanların yararlandığı gerçek özgürlükleri genişletme süreci olarak tanımlanabilir. Bu tanımı açarsak; insanların değer verdiği özgürlükleri genişletmesi sadece hayatlarını daha zengin ve engelsiz hale getirmez, bununla birlikte, iradelerini kullanarak ve içinde yaşadıkları dünya ile etkileşimde bulunarak daha bütünsel anlamda sosyal kişiler olmalarını sağlayabilir (Sen, 2004a:17,29). Kapasite yaklaşımı insan haklarını güçlendirmek için de bir temel sağlamaktadır.

Sen'e gore, insan hakları önemli ekonomik ve sosyal özgürlükleri kapsar. Bu özgürlüklerin kabul edilmesi durumunda, bu hakların kurumların yeterli düzenlemeleri olmaması nedeniyle gerçekleştirilemediği durumlarda, kurumların kapasitelerinin iyileştirilmesi ve güçlendirilmesini yerine getirilmesi zorunlu yükümlülükler haline getirebilir (Sen, 2004b'den akt.: Metin, 2014:6324). İnsanın onuru ve özgürlüğ̈̈, kapasiteler ve insan haklarını ilişkilendiren ortak paydadır. Temel kapasitelerin kazanılamaması yoksulluğa neden olduğuna gore; buradan yoksulluğun bir insan hakları ihlali olduğu mantıksal çıkarımına ulaşılabilir. Osmani, bu akı1 yürütmeyi üç aşamalı olarak açıklamaktadır: İlki; yoksulluk, temel kapasitelerin kazanılmasında bir eksiklik halidir. İkincisi; birçok insan hakkı, bazı temel kapasitelere sahip olma hakkı olarak nitelenebilir. Son olarak; bu nedenle de, yoksulluk bir insan hakkı ihlali olarak görülebilir (Osmani, 2005'ten akt., Metin, 2014:6324).

Dezavantajlı öğrenci gruplarının yoksullukla mücadelede kapasitelerinin arttırılması yönünde çözümlere odaklanılması öğrenci yoksulluğuna daha gerçekçi bir yaklaşımı mümkün kılmaktadır. Üniversite öğrencilerinin yüksek öğrenim kurumlarının bir üyesi olarak burada bulunmalarının en genel amacı da aslında ekonomik, toplumsal ve kültürel olarak kapasitelerini arttırmaktır. Türkiye'de yoksulluk çalışmalarında genellikle mutlak yoksulluk, göreli yoksulluk, yeni yoksulluk ve sınıf dışı yaklaşımları esas alınırken kapasite yaklaşımı üzerinde pek durulmamaktadır.

Farklı sınıflardan, ailelerden gelen üniversite öğrencileri aslında eşitsiz koşullar ve kapasiteleri ile heterojen bir kitledir. Eşitsiz koşul ve kapasiteleri olan öğrenciler eşit koşullar ve kapasitelere sahipmiş gibi tek biçimli bir eğitim ve öğretimden geçmekte ve aslında dile getirilmese de dezavantajlı kapasiteleri nedeniyle daha zor bir hayatı yaşamaktadırlar. Üniversite öğrencilerinin barınmalarından, aldıkları derslerin içeriğine dek bu eşitsizliğin yarattığı dezavantajlar dikkate alınarak yapılabilecek düzenlemeler üzerinde düşünmek ve 
dezavantajı kapasitelere sahip öğrencilere farklı destek mekanizmalarının ücretsiz olarak sağlanması için bu çalışmanın bir başlangıç olabilmesini umut edebiliriz.

Gençlik, sosyal olarak inşa edilmiş çocukluk ve yetişkinlik arasında bir ara aşamadır: Gençlik sadece kronolojik olarak belirli yaş aralıklarına bağlı olarak açıklanamadığı gibi gençliğin bitiş noktası da ücretli bir iş veya cinsel ilişki gibi spesifik aktivitelere bağlı değildir. Fizyolojik gelişim aşamalarına bağlı olan gençlik, ergenlikle başlayan ve bireyin psikolojik ve duygusal yetişkinliğe ulaşmasıyla sonlanan bir dönem olarak ergenlikten daha geniş bir kavramdır (Furlong, 2013:1-2).

Sosyal olarak inşa edilmiş bir kategori olarak gençliğin tanımlanması zordur. Temel olarak, gençliğin, tam bağımlı olarak karakterize edilen çocukluk ile yetişkinliğin bağımsızlığı arasında yarı-bağımlı bir dönem olduğu söylenebilir. Bu şekilde tanımlandığında açıktır ki gençlik, zamana göre ve toplumdan topluma farklı inşa edilir. Bazı toplumlarda genç insanlar nispeten erken yaşlarda bağımsızlığını kazanırken diğerlerinde bağımlılık yirmili yaşlarına hatta daha ötesine dek uzayabilmektedir (Furlong, 2013:2-3).

W. R. Heinz, hayatın bu döneminin koordinatlarının devletin ekonomi, eğitim ve sosyal politikalarına göre değiştiğini söylemektedir. Heinz'e göre, modern toplumlar; eğitim ve öğretim hükümleri, işgücü piyasas1 düzenlemeleri, dışlama mekanizmaları, sosyal yardımlaşma kuralları, hangi ölçüde gençlik politikaları olduğu gibi yaşam geçişleri ile ilgili kendi kurumsal düzenlemelerine göre farklılık göstermektedirler (Heinz, 2009'dan akt.: Furlong, 2013:3).

Gençliğin tanımlanmasında yaşın genellikle belirleyici olduğu ancak genç olarak nitelendirilen kesim için kabul edilen yaş aralığının toplumdan topluma farklılaştığı görülmektedir. Birleşmiş Milletler (BM)'nin Ekonomik ve Sosyal İşler Departmanı'nın Gençlik-Bağlantılı Çalışmanın Gerekçesi adını taşıyan belgeye göre gençlik, 15-24 yaş arasındaki insanlar olarak tanımlanmıştır. Türkiye İstatistik Kurumu'nun da bu yaş aralığını (15-24) temel aldığı görülmektedir. Avrupa Birliği (AB) ise; Gençlik Eylemde (Youth in Action) programlarından yararlanabilme yaşını 15-28, bazı eylemler için 13-30 olarak belirlemiştir (European Union, 2011'den akt.: Deniz, 2014:22). Görüldüğü üzere Avrupa Birliği genç olarak kabul ettiği bireylerin yaş aralığı konusunda daha esnektir.

Üniversite gençliği, gençlik evreninin başta eğitim olmak üzere, farklı bir şehre okumak için gitmek, geçimini burs, kredi ya da harçlıkla sürdürmeye çalışmak, kol kuvvetinden çok beyin gücüyle hayatını kazanmayı amaç edinmek, felsefi-kültürel-sanatsal faaliyetlere çalışan yaşıtlarına göre daha duyarlı olmak gibi çeşitli faktörler sebebiyle özelleşmiş bir parçasıdır (Deniz, 2014:33). Vehbi Bayhan üniversite gençliğini; "18-24 yaş grubunu oluşturan, formel eğitim-öğretimin son evresinde öğrenim gören, araştırmacı ve sorgulayıcı, dolaylstyla bilimsel zihniyet kazanan, kendilerine has bir gençlik kültürü oluşturan, toplumun önderleri olacak gençlik kesimi" olarak tanımlamaktadır (Bayhan, 1997'den akt.: Deniz, 2014:33). Eğitim, kültür ve toplumsal eşitsizlik ilişkilerini çözümleyen Pierre Bourdieu'nün kavram ve düşüncelerine yer vermek böyle bir çalışma için anlam taşımaktadır.

Eserlerinde eğitimin merkezi yer tuttuğu Bourdieu sınıflı toplumlarda kültür ve iktidar arasındaki ilişkileri çözümlemek için eğitim kurumlarını incelemiş, kültürün toplumsal tabakalaşmadaki önemi çalışmalarının ana izleğini oluşturmuştur. Bourdieu'ye göre çağdaş toplumlarda statü ve ayrıcalığın dağılımının denetiminde eğitim kurumları egemen bir rol üstlenmektedirler. Aynı zamanda, kültürel sermayenin çeşitli biçimlerinin oluşumu, birikimi ve aktarımında da temel kurumsal koşulları sağlamaktadırlar. Ona göre, eğitim, gerçekte eşitliksiz bir toplumsal düzenin idamesine; miras alınmış kültürel farklılıklar, akademik başarı ve mesleki firsatların şekillendirilmesindeki rolüyle katkıda bulunmaktadır (Swartz, 2011:263-264).

Bourdieu'ye göre modern sanayi toplumlarında iktidar mücadelesi belli başlı iki toplumsal hiyerarşi ilkesine göre şekillenmektedir. Bunlardan ilki, Bourdieu'nün 'hâkim hiyerarşi ilkesi' adını verdiği ekonomik sermayenin (servet, gelir ve mülk) dağılımı, diğeri ise; "hiyerarşinin ikincil ilkesi" adını verdiği kültürel sermayenin (bilgi, kültür ve eğitim vasıfları) dağılımıdır. Hâkim sınıf bu iki sermaye türüne de hatırı sayılır ölçüde sahip olmakla diğer bütün gruplardan ayrılmaktadır (Swartz, 2011:267-268).

Dezanvantajlı üniversite öğrencilerinin ekonomik sermaye ve kültürel sermaye açısından yoksun oldukları aşikârdır. Bunlardan herhangi birinde artış, diğerini de olumlu yönde etkileyecektir. Bu noktada üniversite öğrencilerinin ekonomik anlamda desteklenmesi kadar sosyal ve kültürel sermayelerini arttıracak her tür etkinlik de önem taşımaktadır.

Habitus kavramı yoksul kesimlerin düşünme ve davranış biçimleri ile değişim ve dönüşüme direnç göstermelerinin altında yatan sosyal psikolojik etkileri kavramak için kullanışlı bir kavramdır. Bourdieu habitus kavramını şu şekilde açıklamaktadır (Swartz, 2011:273); 
KETE TEPE, Nazmiye ve ÖZER, Yavuz - Üniversite Öğrencilerinin Yoksulluk Algısı Üzerine Nitel Bir Araştırma

"Bir toplumsal sinıf ya da statü grubunun tüm üyelerinde ortak olan, kismen kalıcı ve çoğunlukla bilinçdışı olan, bireyin başarı olasılıkları ve toplumun nasıl işlediği hakkındaki görüşlerinden oluşan fikirler kümesi olarak habitus sinı-alt kültürüne yakın bir kavramdir. Bu fikir ya da görüsler diğer bir ifadeyle yatkınlıklar ise bireyleri yaşam olasıllkları ve statü ayrımlarından mürekkep toplumsal yaplyı yeniden üretecek şekilde eylemeye sevk etmektedir. Bourdieu habitus kavramina dayanarak eğitimle ilgili tercihlerin bilinçli ve rasyonel hesaplardan çok yatkınlıklara bağlı olduğunu özellikle belirtmektedir".

Yinelersek habitus kavramı, bireyin sınıfsal kültürüyle ilgilidir ve sınıfsal ortak fikirler kümesini, yatkınlıkları, davranış, eğilim ve alışkanlıklarını temsil eder ve çoğunlukla da bilinçdışı işler. Böylece bireyin sahip olduğu fikir ve davranışlar onu belli kalıplar içinde düşünmeye, tercihlerini de bilinçli bir şekilde vermektense bu kalıplara göre vermesine neden olmaktadır.

Habitus kavramı, kapasite yaklaşımı açısından önem taşıyan bir kavramdır. İnsanın kapisitelerini kullanmasında önemli bir engel olan habitus incelikli bir kavrayış ve analizi hak etmektedir. Habitusun insan üzerindeki olumsuz etkilerini giderebilmek bireyin ekonomik, sosyal ve kültürel anlamda gelişebileceği bir ortam ve hayat koşullarını gerektirmektedir.

Sınıf habitusuna ek olarak, sınıflar arasındaki kültürel sermaye farklılıkları eğitimdeki başarıyı etkilemektedir. Kültürel sermaye, toplumsal eşitsizliğin taşıycısı olarak işlev görmektedir. Bourdieu, özellikle eğitim vasıfları olarak kültürü, enerji zaman ve para karşılığında satın alınabilen ve yüksek statülü meslekler ve gelirlerle mübadele edilebilen bir tür sermaye olarak düşünmektedir. Bourdieu’ya gore, genel kültürel farkındalık, eğitim vasıfları, okul sistemi hakkında malumat ve sözel beceri gibi çeşitli imkânları kapsayan kültürel sermaye eşitsiz dağılmaktadır. Sonuç olarak, toplumsal sınıflar arasında, eğitimde başarı ve kültürel tüketim örüntüleri açısından çok ciddi farklılıklar bulunmaktadır. Ona göre, öğrencinin akademik performansıyla, ebeveynlerinin kültürel geçmişi arasında güçlü bir ilişki vardır. Kısaca söylenirse, ebeveynler kültürel miraslarını çocuklarına aktarmaktadırlar (Swartz, 2011:275). Yoksullukla mücadelede ekonomik eşitsizlikleri gidermek kadar kültürel eşitsizlikleri gidermek de temel amaçlar arasında yer almalıdır. Zira kültürel eşitsizliklerin çoğu zaman ekonomik eşitsizliklerin temelini oluşturabildiği söylenebilir.

$\mathrm{Bu}$ noktada yeniden habitus kavramına dönersek, habitus sosyal köken, bireyin bulunduğu sosyal konum ve eğitim kariyeri arasındaki ilişkilerin kesiştiği noktadır. Okul sadece eğitim ve öğretim sağlayan değil aynı zamanda belli bazı habitusları yeğlediği için sosyal açıdan hem homojenleştirici, hem de eleyici ve ayrıştırıcı olabilmektedir. Bourdieu, eğitimin toplumu yeniden-üretme mekanizması olarak kültürel ve ekonomik sermayeden beslenen habitus üzerinden mümkün olduğunu söylemekte ve yüksek öğrenimin de bu işleyişten azade olmadığını vurgulamaktadır (İdemen, 2008'den akt.: Deniz, 2014:34-35).

Habitus, yapısal eşitsizliğe kültürel açıdan yaklaşmak için bir temel sunmanın yanı sıra eylemlilik üzerine odaklanmayı da mümkün kılmaktadır (Marshall, 1999:291). Bourdieu, habitus kavramını, eşitliksizlik yaratan toplumsal düzenlemelerin nasıl olup da hâkim sınıflara ve tahakküm altındakilere mantıklı gelebildiğini açıklamak için kullanmış ve sosyalleşmenin sınıf temelli niteliğini vurgulamıştır. Sınıfsal durumların nedeni değil bir ürünü olan habitus, bir toplumsal sınıf ya da statü grubu açısından yaygın olan nesnel olasılıkların, çoğunlukla bilinçdışı ve özellikle daha çocukluğun ilk dönemlerinde içselleştirilmesinden doğmaktadır. Habitusun, farklı sınıfsal firsatlara uygun olarak kendini gerçekleştirme olasılıkları yaratan, derinlemesine yapılandırıcı olan bir tür kültürel matrisi temsil ettiği söylenebilir. Buna gore, bireyin eylemi öncelikle sosyalleşme sırasında içselleştirilen temel yatkınlıklardan doğar ve bunlar aracılığıyla düzenlenir. Temel hayat koşulları ise yine Bourdieu tarafından "belirli bir toplumsal grup için olası, olanakl ya da olanaksız olan şeyleri maddi, toplumsal ve kültürel açıdan belirleyen koşullar" olarak tanımlanır (Swartz, 2011:148-150).

Bourdieu'ya göre, habitus bireyleri düzene dolaysız itaate yönlendirmekte böylelikle toplumsal ve ekonomik zorunluluğu erdeme dönüştürmektedir. Bourdieu, benzer hayat olasılıklarını içselleştiren bireylerin aynı habitusu paylaştıklarını söyleyerek habitusun kolektif temelini vurgulamaktadır. Ona göre, farklılaşmış bir toplumda aynı sınıf üyelerinin pratikleri, her zaman faillerin bildiğinden ya da arzu ettiğinden daha fazla ve daha iyi uyum içindedir. Habitusun yatkınlıkları, bilinçli ya da söylemsel bir bilgi türü olmaktan çok, hayata dair bir değerlendirme ve biçimsel hâkimiyet şeklinde pratik bir bilgi türünü temsil etmekte ve bilinçdış1 biçimde oluşmaktadır. Habitus, bir eylemin, belirli bir durumda getireceği başarı olasılığının pratik bir şekilde değerlendirilmesiyle doğmakta, bu değerlendirme ise; gündelik olaylardan, deyimlerden, ortak duyudan, 'böyle şeyler bize uymaz' benzeri etik hükümlerden oluşan bir yap1 üzerinden işlemektedir. Habitusun, sınıflı bir toplumda insana nereye ait olduğu veya olmadığı duygusunu kazandırmaktadır. Bourdieu, iktidarı ve onun meşrulaştırılmasını, habitusun yapısının ve işleyişinin merkezine yerleştirmektedir. Bunun nedeni ise, habitusun 
sınıflı bir toplumda bireyler açısından neyin olanaklı ya da olanaksız olduğunun bilinçdışı bir şekilde hesaplanmasını içermesidir. Bourdieu, olanaklı olanla ilişkinin, iktidarla ilişki olduğunu söylemektedir. Habitusun 'zorunluluk erdemi' dinamiği, bütün toplumsal dünyaların herkese eşit derecede açık olmadığını vurgulamaktadır. Yani bütün eylemler, herkes için mümkün değildir, bazıları mantıklı ve rasyonelken bazıları ise tasavvur dahi edilemezdir (Bourdieu, 1977, 1984 ve 1990'lardan akt.: Swartz, 2011:150-152). Habitusun davranışlarda nasıl açığa çıktığına ilişkin ise Bourdieu özetle şunları söylemektedir (Bourdieu, 1983'den akt: Swartz, 2011:154);

\section{"Habitusun yatkınlıkları eylemin bilişsel, normatif ve bedensel boyutlarını içine alan bir davranış tarzı 'ana örüntüsü'dür. Bunlar dilde, sözel olmayan iletişimde, beğenilerde, değerlerde, algilarda, akıl yürütme tarzlarında ifade bulur".}

Bourdieu'nun habitus kavramlaştırmasından yola çıkarsak, bu; öğrencilerin habituslarının onların benzer sınıfsal köken ve hayat deneyimlerinin ürünü olarak benzer düşünüş, yatkınlık ve davranış örüntüleri ortaya koyabileceği fikrini doğurmaktadır.

Gençlik, hayatın en üretken olunabilecek bir evresidir. Habitus kavaramı göstermektedir ki; bireyin yetersiz ekonomik, sosyal ve kültürel hayat koşulları onun fikir, düşünce, davranış ve hayata katılımını belli kalıplar ve sınırlara hapsetmektedir. Bu durum ise karşımıza "yapabilirlik" sorununu çıkarmaktadır. Birey kendisine küçük hedefler belirlemekte, daha ötesini yapabileceğini hayal dahi edememektedir. Bu ise geniş bir gençlik kesiminin enerjisinin, yaratıcılığının ve yapabilirliğinin heba edilmesi anlamına gelmektedir.

\section{ARAŞTIRMANIN YÖNTEM VE ANALIZI}

Gençlik konusundaki araştırmaların artmasının, gençliğin sorunlarının daha doğru tespit edilmesine ve insanların gençlik dönemlerini yaşama dönük, mutlu, yaratıcı, hayatı dönüştürebilmek ve tercih ettiği hayatı kurabilmek için kapasitelerini geliştirebilecekleri koşul ve imkânlarla geçirmesi ile hak ve özgürlükleriyle yaşayabilmesi için yasal olarak da desteklenen gençlik politikalarının oluşmasına katkı sağlayacağını söyleyebiliriz.

$\mathrm{Bu}$ çalışmada Afyon Kocatepe Üniversitesi'nin çeşitli fakültelerinde (70 öğrenci) ve Afyon Meslek Yüksekokulunun farklı programlarında okuyan (30 öğrenci) toplam 100 öğrenciyle nitel araştırma yöntemlerinden biri olan derinlemesine görüşmeler gerçekleştirilmiştir. Görüşmeler öğrencilerin sosyal kökenine ve gelir düzeyine bakılmaksızın öğrenci evlerinde, kampüste ve sınıflarda karşılaşılan, zamanı ve isteği olan öğrencilerle yapılmıştır. Dolayısıyla örneklem türü, rastgele örneklemdir. Görüşmeler 2014 yılının Mart-Haziran aylarında gerçekleştirilmiş ve yarı yapılandırılmış derinlemesine görüşme tekniği kullanılmıştır. Görüşmeler ses kayıt cihazıyla kaydedilmiş, kayıtların transkripsiyonu sonucunda 296 sayfalık bir metne ulaşılmış, araştırmanın bulguları da bu metnin sosyolojik bir yaklaşımla incelenmesi sonucunda ortaya çıkmıştır.

Philipp Mayring, insan bilimlerinin konusunun daima insanlar yani özneler olduğunu ve araştırma sorularının muhatabı olan öznelerin araştırmanın kalkış noktası ve esasını oluşturduğunu söylemektedir. Mayring, nitel düşüncenin temel niteliklerini; araştırmanın güçlü bir biçimde özneye ilişkinlik ilkesine dayanması, araştırmaya konu olan öznenin betimlenmesi ve yorumlanmasına önem verilmesi, öznenin kendi doğal, gündelik yaşam ortamı içinde araştırılması ve araştırmanın sonucundan ise bir genelleştirme sürecinin anlaşılması gerektiği şeklinde özetlemektedir. Mayring, nitel düşüncenin nicel düşünceye bir seçenek oluşturmadığını, nitel ve nicel düşüncenin kural olarak her araştırma sürecinde mevcut olduğunu özellikle belirtmektedir. Ancak, Mayring'e göre, bir dönem araştırmalarda nitel düşüncenin, ihmal edilmesinin araştırmalarda çarpıtılmış ve kullanılmayacak verilerle sonuçlanması nedeniyle, araştırma ve bilme sürecinde yeniden öne çıkarılması gerekmektedir (Mayring, 2011:25-26).

W. Lawrence Neuman'a göre, “nitel araştırmacılar ham verilerin zenginliği, dokusu ve yarattığı hisle daha çok ilgilenir, çünkü onların tümevarımcı yaklaşımı toplanan verilerden yola çıkarak anlayışlar ve genellemeler geliştirmeyi vurgular" (Neuman, 2017:221).

Nitel araştırmada kişilerin kanaatleri, deneyim, algı ve duyguları gibi subjektif verilerle ilgilenilmekte, bir sosyal olay ya da olgu doğal ortamı içinde tasvir edilmekte ve zaman alıcı olması nedeniyle veri toplamak için küçük örneklemler üzerinde çalış1maktadır (Arıkan, 2017:21-22). Üniversite öğrencilerini konu alan nitel çalışmalarda 80, 60 hatta daha az sayıda öğrenciyle görüşüldüğü örneklere rastlanmıştır. Örneklemin küçük olmasına rağmen tek tek katılımcıların gündelik hayat pratiklerinden, deneyimlerinden, duygu, fikir ve 
düşüncelerinden oluşan zengin bir veriye, konu ya da soruna dair geniş bir perspektife ve anlamlı sonuçlara ulaşılabilmektedir.

Niteliksel araştırmacılar anlamla ve yaşantıyla yani insanların dünyayı nasıl anlamlandırdıkları ve yaşantıladıklarıyla ilgilenmektedirler. Niteliksel araştırmada ortaya çıkan bilgi genellikle tasvirler ve açıklamalar halindedir. Böylece toplum içinde açıklamaları önemsenmeyen ya da toplum dışına itilenlerin sesleri işitilebilir. Bu sesleri doğrudan duyurmak, bu tür araştırmanın hedeflerinden biridir (Arkonaç, 2014:26).

Nitel araştırmada belli bir kesimin belli bir olgu ya da soruna ilişkin düşünce ve anlam dünyasının tasviri, betimlenmesi amaçlanmaktadır. $\mathrm{Bu}$ tür araştırmada insanların özneler olarak ele alınması esastır. Nitel araştırma, araştırmacıyla araştırmaya konu olan özneler arasında etkileşimli bir diyalog olarak görülebilir. Özneler bizzat olgu ya da sorunu deneyimleyenler olarak olgu ya da soruna dair içeriden ve daha doğru bir yaklaşımla fikir ve düşünce üretebilmektedirler. Araştırmacı böylece olgu ve sorunlara ilişkin dışarıdan bir gözlemcinin yaklaşımından elde edilen verilerden çok daha fazla zengin duygu, fikir ve düşünceye sahip bir içeriğe, veriye ulaşabilmektedir.

\section{ARAŞTIRMANIN BULGULARI}

Öğrencilerle kampüste, sınıflarda ve öğrenci evlerinde bir araya gelerek yapılan görüşmelerde öğrencilerin konuya ilgiyle yaklaştıkları, düşüncelerini açıkça ifade etmeye çalıştıkları söylenebilir. Araştırma bulguları "Öğrencilerin profili", "öğrencilerin sosyo-ekonomik durumu”, "öğrencilerin yoksulluk algısı" ve son olarak "farkınadalıklar, öneriler ve çözümler" başıkları altında açıklanmıştır.

\section{1. Öğrencilerin Profili}

Katılımcıların 53'ü erkek ve 47'si kadın öğrencilerden oluşmaktadır. Katılımcıların yaş aralığına baktığımızda: 18 ve altı yaş aralığında 6öğrenci; 19-20 yaş aralığında 27 öğrenci; $21-22$ yaş aralığında 30 öğrenci; 23-24 yaş aralığında 26 öğrenci; 25-26 yaş aralığında 10 öğrenci ve 27 ve üstü yaş aralığında ise 1 öğrenci bulunmaktadır.

Grafik 1. Katılımcıların Yaş Aralı̆̆ı

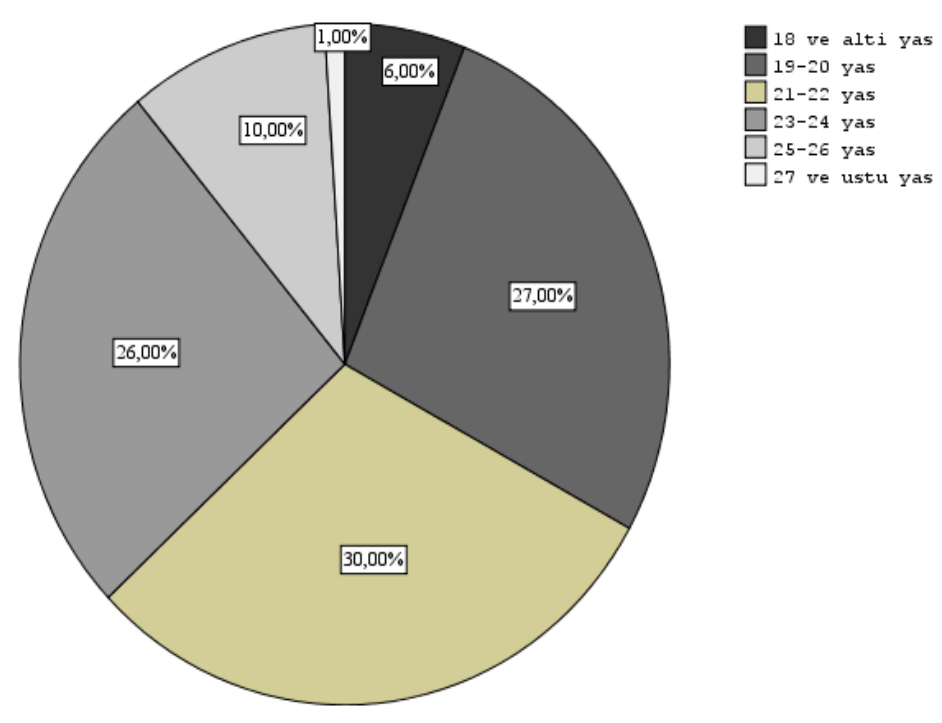

Katılımcıların ailelerinin yaşadığı coğrafi bölgelere baktığımızda: ailelerin yüzde 34'ü İç Anadolu; yüzde 19'u Ege; yüzde 18'i Marmara; yüzde 10'u Akdeniz; yüzde 7'si Karadeniz; yine yüzde 7'si Doğu Anadolu ve yüzde 5’i Güney Doğu Anadolu bölgelerinde yaşamaktadırlar.

\section{2. Öğrencilerin Sosyo-Ekonomik Durumu}

Öğrencilerin ortalama aylık gelir düzeylerine baktığımızda (Tablo-1) ; 300 TL ve altı gelir grubunda 14 öğrenci; 301-500 TL gelir grubunda 22 öğrenci; 501-700 TL gelir grubunda 33 öğrenci; 701-900 TL gelir grubunda 18 öğrenci ve 901 TL ve üstü gelir grubunda ise 13 öğrenci yer almaktadır. 
Tablo 1. Öğrencilerin Ortalama Aylık Gelir Düzeyleri

\begin{tabular}{|c|c|}
\hline Gelir Grubu & Yüzde (\%) \\
\hline 300 TL ve alt1 & 14 \\
\hline $301-500 \mathrm{TL}$ & 22 \\
\hline $501-700 \mathrm{TL}$ & 33 \\
\hline $701-900 \mathrm{Tl}$ & 18 \\
\hline $901 \mathrm{TL}$ ve üstü & 13 \\
\hline
\end{tabular}

Öğrencilerin gelirlerinin kaynağına ilişkin sorulardan elde edilen veriler ise Tablo-2'de görüldüğü gibi şöyle özetlenebilir: Öğrencilerin 53'ü Kredi ve Yurtlar Kurumu'ndan geri ödemeli aylık 300 TL kredi almaktadır. Öğrencilerin 25 'i burs almaktadır. Öğrencilere burs veren kurum ve kuruluşlara bakıldığında ise şu bilgilere ulaşılmıştır. Öğrencilerin 13'ü aylık 300 TL Başbakanlık bursu almaktadır. Öğrencilerin 5'i aile yakınları tarafindan desteklenmektedir. Öğrencilerin 4’ü dernek ve vakıflardan, 2'si özel şirketlerden, 1 öğrenci de üniversite vakfından burs almaktadır. Bunun yanı sıra öğrencilerin $85^{\prime}$ 'inin gelirinin büyük kısmını aileleri göndermektedir. Öğrencilerin 5'inin gelir kaynakları arasında çalışarak kazandıkları ücret bulunmaktadır. Öğrencilerden 1'i ise aldığ yetim aylığı ile geçinmektedir. Yine elde edilen bir başka sonuç da şudur: Öğrencilerin 7'si sadece Kredi ve Yurtlar Kurumu'ndan aldığg aylık 300 TL'lik kredi ile geçinirken, 23'ü sadece ailelerinin gönderdikleri para ile geçinmekte ve 2'si ise sadece çalışarak elde ettikleri gelir ile geçinmektedir.

Tablo 2. Öğrencilerin Gelirlerinin Kaynağı

\begin{tabular}{|c|c|}
\hline Gelir Kaynă̆ı & Öğrenci Sayısı \\
\hline Kredi ve Yurtlar Kurumu & 53 \\
\hline Başbakanlık bursu & 13 \\
\hline Yakınları tarafindan verilen burs & 5 \\
\hline Dernek ve vakıflardan verilen burs & 4 \\
\hline Özel şirketlerin verdiği burs & 1 \\
\hline Bir işte çalışan & 5 \\
\hline Yetim aylığı & 1 \\
\hline Sadece KYK Kredisiyle geçinen & 7 \\
\hline Sadece aile desteğiyle geçinen & 23 \\
\hline Sadece kendi çalışmasıyla geçinen & 2 \\
\hline
\end{tabular}

Öğrencilerin istihdam durumuna ilişkin sorulardan elde edilen veriler şunlardır: Öğrencilerin 89'u herhangi bir işte çalışmamaktadırlar. Görüşme yapılan öğrencilerden 11'i çalışmaktayken, 7'si çalışmak için iş aramaktadır. Öğrencilerle yapılan görüşmelerden edinilen izlenim, öğrencilerin sigortasız, uzun saatler ve düşük ücretlerle çalıştırılmasının sıkça rastlanan bir durum olduğudur. Öğrencilerin genellikle çalıştıkları sektörler gıda, giyim ve otelciliktir.

Öğrencilerin barınma için tercih ettikleri ya da uygun gördükleri barınma mekânları incelendiğinde ise şu verilere ulaşılmıştır. Öğrencilerin 43'ü kiralık evde yaşamaktadır. En az 2 öğrenci olmak üzere 6 öğrenciye kadar ortaklaşa ev kiraladıkları görülebilmektedir. Ev kiralarının da 400 ile $800 \mathrm{TL}$ arasında değiştiği görülmektedir. Devlet yurdu ve özel yurtlarda kalan öğrenci sayısı ise, her ikisi için de 25 'dir. Öğrenciler KYK'nın yurtları için aylık 120 TL ödemektedirler. Özel yurtların aylık ücretleri ise 250'den 550'ye kadar çıkabilmektedir. Gelirlerini toplumsal hayata katılım için yeterli görüp görmedikleri sorusuna öğrencilerin 40’1 yetersiz, 24'ü kısmen yeterli, 36'sı ise yeterli yanıtını vermiştir. Elbette 100 öğrenciyle yapılan görüşmeler neticesinde elde edilen bu niceliksel veriler genele yansıtılmak için yeterli değildir ancak yine de bir fikir verdiği söylenebilir. Son olarak yapılan görüşmelerde öğrencilerin yaşam koşullarına ilişkin bir kabullenme içinde oldukları ve durumlarını doğal bularak bir sorgulama içine girmedikleri görülmüştür.

Bourdieu ve Passeron'a göre, farklı yaşama veya çalışma koşullarıyla başarı şartlarını tanımlayan toplumsal köken; tüm belirleyici faktörler arasında başta varoluş koşulları olmak üzere öğrenci deneyimlerinin tüm seviyelerinde, etkisini bütün alanlarda gösteren tek faktördür (Bourdieu ve Passeron, 2015:28). Bireyin toplumsal kökeni sosyo-ekonomik koşullarının ürünüdür. Yani doğduğu ve yaşadığı yer, aldığı eğitim, mesleği, gelir düzeyi, sahip olduğu ekonomik, sosyal ve kültürel sermayenin toplamı o kişinin toplumsal kökeniyle yakından ilişkilidir. Bu çalışma açısından öğrencilerin ailelerinin sosyo-ekonomik koşulları, aldıkları eğitim, 
gelir düzeyleri, anne babanın çalışıp çalışmaması, meslekleri öğrencilerin toplumsal köken olarak hangi toplumsal sınıftan olduklarını da göstermektedir. Bu açılardan bakıldığında öğrencilerin çoğunlukla alt ve altorta sinıftan olduğu görülmekte, az da olsa orta sinıftan öğrenciler de bulunmaktadır. Bu projede elbette öğrencilerin toplumsal sınıflarını net bir biçimde araştıracak ve ortaya koyacak bir çalışma yapılmamıştır. Ancak anne babaların eğitim durumları, gelir düzeyleri ve mesleklerinin incelenmesi sonucunda böyle bir çıkarımda bulunulmuştur.

Öğrencilerin toplumsal kökenleri aynı zamanda onların sahip oldukları ekonomik, sosyal ve kültürel sermayeleri hakkında işaretler vermekte, öğrencilerin habitusunu da oluşturmaktadır. Bourdieu ve Passeron öğrencileri toplumsal bir kategori olarak ele almakta ve toplumsal kökenleri ile de bağlantılı olarak şu düşünceyi ortaya koymaktadırlar: "Eğitim sisteminin kullanıcıları olarak ögrenciler, aynı zamanda bu sistemin birer ürünüdürler ve mevcut tutum ve kabiliyetleri, geçmişteki kazanımlarının alametini bu kadar taşıyan başka bir toplumsal kategori yoktur" (Bourdieu ve Passeron, 2015:29).

Bourdieu ve Passeron'a (2015:108) göre; toplumsal eşitsizliklere ilişkin körlük, tüm eşitsizliklerle birlikte özellikle eğitimsel başarıyla ilgili olanları yetenek eşitsizlikleri yani doğal eşitsizlikler olarak açıklama eğilimindedir. $\mathrm{Bu}$ eğilimin ortaya çıkardığı aynı tutum, öğrenim gören herkesin biçimsel eşitliği temel varsayımına dayanan ve bireysel yetenek kaynaklı eşitsizliklerden başkasını kabul edemeyen bir sistemin mantığında da bulunmaktadır. Bourdieu ve Passeron, günümüzde ve ülkemizde de tanık olduğumuz, bu ve buna benzer öğrencilerle eğitimsel olarak karşılaşılan sorunlarda hocalar tarafından dile getirilen söylenmelerin eleştirisini ise şu yalın gerçekle birlikte ifade etmektedirler (Bourdieu ve Passeron, 2015:108);

\section{"Söylenerek 'günah çıkartma', ögrencilerin kültürü ile toplumsal kökenleri arasındaki bağlantıyı savmaya imkân tanır; özellikle yoğun yetersizlikler şeklinde kendini dayattı̆̆ında. Mütevekkil yakınmayla 'öğrencilerin artık okumadı̆̆ını' veya 'seviyenin her geçen yıl düştüğünü' söylemek, aslında bunun neden böyle olduğunu kendine sormaktan ve devamında da bunun pedagojik sonuçlarını çıkarmaktan kaçınmaktır".}

Kuşkusuz yüksek öğretimde birçok bileşen bulunmakta ve öğrencilerin toplumsal kökenleri, gelir düzeylerine bağlı olarak yaşadıkları yoksulluk ve yoksunlukların onları eğitim hayatları boyunca ne tür problemlerle karşılaştırdığı ve bunlara çözümler üretilmesi tüm bileşenlerin öneri ve katkılarıyla ve yasal düzenlemelerle de bu önerilerin desteklenmesiyle mümkün olabilecektir. Ancak üniversite öğrencisinden üniversite yönetimine, öğretim elemanından, eğitimle ilgili sivil toplum örgütlerine dek her bir bileşenin kendi içerisinde de yapacağ çalışmalar, öneri ve katkılar olabileceği aşikârdır.

Öğretmenlerin bu konudaki çalışmalarına örnek olarak Leblanc-Esparza ve Roulston'un “Breaking the Poverty Barrier" (Yoksulluk Engellerini Yıkmak) adlı çalışmalarında anlattıkları, başarıya da ulaşan bir takım yeni ilke ve hedefler koyarak ve iletişim sistemini değiştirerek gerçekleştirdikleri yöntemleri gösterilebilir.

Leblanc-Esparza ve Roulston (2012:1) özetle; insanların birlikte çalışabileceği güçlü bir liderlik geliştirdiklerini, öğrencilere gerçekte neden çalışmakta olduklarını bilmelerini sağlamak için kılavuzluk ettiklerini, aileleri öğrencilerin eğitimini yönetmeye dahil ettiklerini, neyi daha iyi yapmaları gerektiğini anlamak için verileri kullandıklarını, stratejik okuryazarlık müdahaleleri uyguladıklarını, sahip oldukları öğrenci nüfusu için okul çapında stratejiler geliştirdiklerini, profesyonel öğrenme amaçlı personel toplulukları oluşturduklarını ve negatif inançları başarı kültürünün yaratılmasıyla değiştirdiklerini söylemektedirler. Burada örnek gösterilen çalışma yüksek öğretim için değildir. Ancak biraz üzerinde düşünülüp çalış1lırsa yüksek öğretimde yapılabileceklerin bu örnekte gösterilenden farklı olmakla birlikte çok daha çeşitli olabileceği söylenebilir çünkü yüksek öğretimin kurumsal gücü, özerkliği, bileşenleri çok daha fazladır.

\section{3. Öğrencilerin Gündelik Hayatı}

Öğrencilerin gündelik hayatlarını nasıl geçirdiklerine ilişkin sorulara verdikleri cevaplarda ağırlıklı olarak hafta içi beş gün boyunca hayatlarının ev-okul ya da ev-yurt arasında geçtiği görülmektedir. Hafta sonu ise özellikle bir gün farklı bir şekilde geçirilmeye çalışılmaktadır. Öğrencilerin ekonomik koşulları kötüleştikçe öğrencilerin dışarı çıkmaktan kaçındıkları söylenebilir. Ekonomik koşulların iyice kötüleştiği, okula gidecek yol parası bulunmadığı ya da yemek için para olmadığı zamanlarda öğrencilerin sürekli uyuyarak bu süreci unutmaya ya da atlatmaya çalıştıkları örneklere de rastlanmıştır. Genel olarak öğrencilerin kafelere, alışveriş merkezlerine gitmeyi, erkek öğrencilerin halı saha maçları yapmayı tercih ettikleri söylenebilir. 
Burada 2 öğrenciyle ilgili dikkate çekici örnek üzerinde durulacaktır. Bu 2 öğrenci dernek ve oda üyesidir. Bu öğrencilerin daha yoğun olduğu ve gündelik hayatlarından söz ederken sıkıcılık ve bıkkınlık içinde olmadıkları görülmektedir:

"Bir günüm sabahlart derste geçiyor bazen. Öğleden sonra hastaneye geçiyorum. Bir hafta sabah hastanede oluyorum ondan sonraki süreçte de dernekte oluyorum. Hafta sonu da dernekte etkinlik falan varsa orada oluyorum onun dişında arkadaşlarımla zaman geçiriyorum, hiç boş vaktim olmuyor" (Seren, Biyoloji, 3. sinıf).

“Şimdi ben, IMO'dayım. IMO sinıf temsilcisiyim İnşaat Mühendisleri Odası'nda. Etkinliklerimiz oluyor, teknik gezilerimiz oluyor. Onları ayarlıyoruz. Makarna yarışması yapacă̆ız şimdi onunla uğraşlyoruz. IMO'yla toplantılara katıllyorum. Ders çıkışları ĕger sinav zamanı değilse arkadaşlarla dişarda sosyal aktivite bowlingdir, sinemadır oturup yüz bir falan oynuyoruz. Sinav zamanı zaten sürekli okul-sinav oluyor. Onun dışında şehir gezileri oluyorsa ona katıllyorum" (Esra, İnşaat Mühendisliği, 2. sınıf).

Öğrencilerin gezmeye, farklı yerler ve şehirler görmeye, gezilere katılmaya yönelik bir istek ve özlemleri olduğu ancak çoğunun bunu maddi olarak karşılayamadıkları görülmektedir. Görüşme yapılan öğrencilerden sadece ikisi gezmeye bütçe ayırabildiğinden, gidip gördükleri yerlerden söz etmiştir.

\section{4. Öğrencilerin Kültürel Yaşamı}

Öğrencilerin kültürel yaşamına ilişkin bulguların ortaya koyduğu durum öğrencilerin popüler kültür ürünlerini tüketmeye eğilim gösterdikleri şeklinde özetlenebilir. Çoğunlukla kültürel yaşamlarında yerli ve yabancı diziler, filmler, çoksatar listelerinde yer alan ya da reklamı yapılan kitaplar ve kişisel gelişim kitapları ile popüler müziklerin ağırlıklı olarak tüketildiği söylenebilir.

İç Mimarlık ve Çevre Tasarımı 1. sınıf öğrencisi Murat (17) kültürel yaşantısındaki eksiklik olarak gördüğü şeyleri çocukluğundaki mahalle yaşantısına bağlamaktadır:

"Açıkçası kültürel olarak şöyle bir geçmişim var mahallede büyüyen bir çocuğum yani az çok çocukluğumuzu mahallede, sokak aralarında geçirdik yani şöyle haftada ya da ayda bir kitap okuma alışkanlığım yok açıkçası. Müzik olarak da klasik nasıl desem ortam ă̆ırlık olarak dinlenilen müzikleri dinliyorum yani özel olarak tercih ettiğim bir şey olmadı. Şiir okumayı severim ama o da psikolojik durumlarda yani sürekli şiir okumak diye bir alışkanlığım yok. Televizyonla pek fazla bir bağımlılığım yok yani fazla sağlıklı bulmuyorum açıkçası".

Çağdaş Türk Lehçeleri ve Edebiyatı 3. sınıf öğrencisi Baran (21) kültürel yaşantısını şu sözlerle ifade etmektedir:

"Ben genelde kitap okumam. Yani merak ettiğim bir șey olursa internetten bakartm hani uzun uzadiya kitap açıp okumam. Bunu birinci sınıfta yurttayken biraz birkaç kitap okudum filan daha sonrasinı şey etmem zaten. Divan edebiyatına biraz merak saldım geçen sene filan şiirleri filan böyle kafiyeli filan onları okurdum sonra ondan da vazgeçtim".

Görüşülen öğrencilerden 12'si kitap okumadığını, okumayı sevmediğini ifade etmiştir. Kitap okuyan öğrencilerin ise okunan bir kitabın sürükleyici olmasını esas aldıkları görülmektedir. Öğrencilerin kültürel tüketiminde fillm ve dizi izlemenin ağırlık kazandığı söylenebilir. Öğrencilerin çoğu "her tarz müzik", "her türlü müzik", "kulağa hoş gelen tüm müzikleri" dinlediklerini ifade etmektedirler. Bu da öğrencilerin çoğunun rastlantısal olarak karşılaştıkları müzikleri dinlediklerini, müzik konusunda seçici olmadıklarını göstermektedir.

\section{5. Öğrencilerin Kişilik Yapıları Açısından Kendilerine Yönelik Algıları}

Öğrencilerin kişilik yapılarına ilişkin sorular daha çok duygu durumlarını ve bu duygu durumlarının yoksulluk ya da yoksunlukla ilişkilendirilebileceği anlamlı ifadeleri, durumlanı açığa çıkarmak amacıyla sorulmuştur. Öğrencilerden özellikle 3'ünün ifadeleri bu bakımdan anlam taşımaktadır:

Çağdaş Türk Lehçeleri ve Edebiyatı 3. sınıf öğrencisi Baran'la 2 öğrenci arkadaşıyla birlikte yaşadıkları evde görüşülmüştür. Görüşmeleri yapmadan önce evde öğrencilerle yapılan sohbet sırasında ev arkadaşları tarafindan 
Baran'ın sürekli uyuduğu, onlarla ortaklaşa bir şeyler yapmaktan uzak durduğu için eleştirilmesine tanık olunmuştur. Baran'la yapılan derinlemesine mülakatta uyuma isteğinin altında yatan temel nedenin yoksulluk ve yoksunluğun yarattığı sorunlardan kaçış olduğuna dair bir izlenim ortaya çıkmıştır:

“(...) uyurum çünkü uyuyunca bir şey falan aklıma gelmiyor daha çok hoşuma gidiyor. (...) Bu bazen kafamı kurcalayan hep bazı sorular olur gelecekle ilgili olsun veyahut da özel yaşantımla ilgili olsun bunları düşünmemek için erkenden uyumaya çalışırım bu yüzden erkenden uyurum. Film izlerim, film izleyince de uykum gelir en azından gözüm yorulur gözüm kızarır öyle en azından uyumaya çalışırım yani”.

Harita Mühendisliği 4. sınıf öğrencisi Cenk (22) kendisinden bahsederken karamsarlığının bir tür umutsuzluk, çaresizlik duygusuyla ilgili olabileceğini düşündürmektedir. Yapılan görüşmelerde öğrencilerin çoğunda yaşam koşullarına ilişkin bir kabullenme içinde oldukları ve durumlarını doğal bularak bir sorgulama içine girmedikleri görülmüştür. Cenk ise kendisinden bahsederken bu sorgulamayı bir ölçüde gerçekleştirmektedir;

\begin{abstract}
"Karamsar değilim hiç diyemem. Karamsarlık var. Çünkü öyle bir şey var ki sürekli dört senede bir sınava giriyorum. Elimden geleni yapmaya çallşıyorum ki ileride iyi bir mesleğim, iyi bir işim olsun diye. Devlete girmeye çalışlyorum. Ama şöyle bir şey var: Tabi insan sıkllmıyor değil. Bazen slkıliyor. Diyorum ki: Hayatta robot muyum? Hayatta farklı şeyler yapmak istiyorum. Dışarıda çılıp ne bileyim her zaman yapmadı̆̆ım bir şey yapmak istiyorum ama olmuyor. Yapamıyorsun. $O$ da insanı karamsarlığa itiyor. (...) Açıkçası biraz daha spor yapmak isterdim. Hiç spor yapmadım. Küçüklükten beri de yapmadım. Bir spor dallyla uğraşmak isterdim. Aynı şekilde yüzmekten, yüzmeyi çok severdim. Yüzmek isterdim. Sosyal imkânım el verseydi neredeyse her hafta giderdim, yüzerdim".
\end{abstract}

İnşaat Mühendisliği 2. sınıf öğrencisi Yaşar'ın (21) anlattıkları da yoksulluk yaşantılarının ne boyutlarda olabileceğinin bir örneğini göstermektedir. Yaşar deneyimleri sonucunda "hayata başkaları gibi bakamayacă̆ını" söylemektedir:

\begin{abstract}
"Duygusalım, benim babam hasta olduğu için, ben hayata abimin hasta olmasını bir kenara bırakıyorum, bir kenara bırakmıyorum o bir dip not da. Aynı zamanda küçüklügüumden beri babam benim ezilmiş bir insan, çocukluğunu yaşayamamış sürekli ezilmişs bir insan. Onun için bu ezilmişliği bizim üzerimizden çıkardl. Bizim üzerimizden çıkarmış derken çok sinirli bir insan en ufak bir şeyde gelip bizi döverdi. Bizi döverdi derken biz zorla işe giderdik zorla derken daha gitmemişim zorla hem de gitmişken kesin dayağ yerdik. Ben sürekli hafta sonu tatilde okulda öğlenciysem öğleden sonra, hafta sonu da işe giderdim, 3 ay tatilde de işe giderdim 15 tatilde de işe giderdim. O yüzden ben buraya gelene kadar normal bir hayat, yani her çocuk gibi bir hayat yaşamadım. Onlar gibi bakamıyorum hayata".
\end{abstract}

\title{
4.6. Öğrencilerin Kendilerini İfade Edebilmeleri Konusundaki Düşünceleri
}

Öğrencilerin kendilerini ifade edebilmeleri konusundaki soruya verdikleri yanıta göre öğrencilerden 74 'ü kendilerini ifade edebildiklerini, 7'si ifade edemediklerini, 19'u ise bazı ortam ve kişilerin yanında ifade edebiliyorken, bazı ortam ve kişilerin yanında ifade edemediklerini belirtmişlerdir.

Kendilerini ifade edemeyen ya da bu konuda sorun yaşayan öğrencilere bakıldığında bir kısmının bunu, çekingen ya da heyecanlı olmaya bağladıkları görülmektedir. Öğrencilerin çoğu; kendilerini akran grupları içinde daha rahat hissedip, kolayca ifade edebildiklerini; ailede, okul hayatında ya da toplumda ifade edememe sorunuyla karşılaştıklarını belirtmektedirler. Öğrenciler bu durumu "anlaşılmamak", "kaale alınmamak", "dinlenmemek", "önyargılar" gibi nedenlere bağlamaktadırlar.

Öğrencilerin aileleriyle ve okul yaşamında sessiz kalmayı tercih etme durumları söz konusu olabilmektedir. Bu durum ifadede sorunlar yaşayan öğrenciler için olduğu kadar kendini çok iyi ifade edebildiğini düşünen öğrenciler için de geçerlidir. Gençliğin maddi ve manevi olarak aileye bağımlı olunan bir ara dönem olması nedeniyle, öğrencilerin aileleriyle sorun yaşamamak için zaman zaman kendi düşüncelerini ifade etmedikleri, istek ve hayallerinden vazgeçtikleri söylenebilir. Aynı durum okul hayatında da söz konusu olabilmektedir. Öğrenciler olumsuz tepkilerle karşılaşmamak için ve sınıfta kalma korkusuyla kendi görüş ve düşüncelerini açıklamayıp sessiz kalmayı tercih edebilmektedirler. 


\section{7. Öğrencilerin Kendilerine Kurmak İstedikleri Hayat ve Hayalleri}

Öğrencilerle gelecekte kurmak istedikleri hayat ve hayalleriyle ilgili düşünceleri sorulduğunda öğrencilerin öncelikli olarak iş sahibi olmak, evlenmek, ev, araba sahibi olmak istedikleri görülmüştür. Öğrencilerin çoğunlukla "standart bir hayat" olarak adlandırdıkları gelecekteki hayatlarını mütevazı, sakin ve huzurlu bir hayat olarak tasvir ettikleri görülmektedir. Az da olsa beklenti düzeyi daha yüksek olan öğrenciler de bulunmakla birlikte genel olarak öğrencilerin pek hayal kurmadıkları iş, eş, ev ve arabayla sınırlı bir yaşam tahayyülü içinde oldukları gözlemlenmiştir.

Öğrencilerin geleceğe yönelik istek ve hayallerinin genellikle toplumun ve ailelerinin de onlardan beklediği iş ve evlilikle çizilmesi bir seçeneksizliği de göstermektedir. Uluslararası Ticaret ve Finansman Bölümü, 4. sınıf öğrencesi Leyla (24) öğrencilerin içinde bulunduğu seçeneksizliği aslında çok güzel ifade etmektedir:

"Çok büyük hayallerle geliyor insan sonradan eğitim, iş, belli bir süreden sonra aileden bağımsızlık... Maddi anlamda, ekonomik anlamda bağımsızlı̆g düşününce mecburen sistemle bütünleşip, sistemin açtı̆̆ kadroyla yer edinmeye çalışlyor insan. Bilmiyorum umarım benim böyle monoton bir hayatım olmaz. Şu anlık düşündüğ̈̈m KPSS ama ileride farklı şeyler çıkar belki. (...) Ekonomik bağımsızlığım olsaydı bir mesleği yapma zorunluluğu hissetmeseydim daha çok toplumsal olaylarla daha çok bir gazetede ya da insani değerlerle vakıflarda çalışmak çok isterdim".

Sosyoloji 4. sınıf öğrencisi Mesut ise toplumda "maddiyat"ın değer kazanmış olmasına dikkat çekmektedir. Ona göre "verimli olmak" bir değer olabilse, öğrenciler de kendilerini daha fazla geliştirebileceklerdir. Böylece ögrenciler iş bulma ve para kazanma baskısından bir ölçüde kurtulup daha önemli gördükleri istek ve amaçlara yönelebileceklerdir.

Görüşme yaptığımız öğrenciler içinde çalışma hayatına atılınca ailesine destek olmak isteyen bir kesim de bulunmaktadır. Bu kesimdeki öğrenciler ailelerinin onları okutmak için fedakârlık ettiklerini ve zorluklar yaşadıklarını görmekte, onlara kendilerini borçlu hissetmekte ve bu borcu ödemek istemektedirler.

\section{8. Öğrencilerin Toplumun Gençlere Verdiği Değer Hakkındaki Düşünceleri}

Öğrencilerin toplumun onlara değer vermesi konusundaki algılarının pek de olumlu olduğu söylenemez. Yapılan görüşmelerden çıkan sonuca göre; öğrencilerin yüzde 58'i gençlere değer verilmediğini, yüzde 22'si değer verildiğini, yüzde 20'si ise kısmen değer verildiğini söylemektedirler.

\section{9. Öğrencilerin Yoksulluk Algısı}

Burada ilk olarak; öğrencilerin yoksulluktan ne anladıkları, onu nasıl tanımladıkları, kavrama ilişkin düşünce repertuvarları ortaya çıkarılmaya çalışılmıştır.

\subsection{1. Öğrencilerin Yoksulluk Tanımları}

Öğrencilerin yoksulluk tanımlarına bakıldığında ağırlıklı olarak ekonomik referanslı yoksulluk tanımları yaptıklarını ve bu tanımların da daha çok mutlak yoksulluğu tanımladığı görülmektedir. Az da olsa göreli yoksulluk ve insani yoksulluk tanımları da öğrencilerin yoksulluk tanımları içinde yer bulmaktadır.

Buna göre ekonomik referanslı yoksulluk tanımlarında öğrencilerin kullandıkları ifadeler şunlardır: "Açlık sınırının altında olmak", "maddi açıdan yetersiz olmak", "belli bir standardın altında olmak, parası olmamak", "temel ihtiyaçlarını karşılayamamak", "eğer kişi giyinmekten barınmaya, karnını doyurmaya kadar temel ihtiyaçlarını karşılayamıyorsa bu yoksulluktur", "insanın yaşamı sürdürebilmesi için zorunlu ihtiyaçları karşılayamamasıdır", "karnı tok, sırtı pek olmamak", "bir gün içinde yemek bulamamak, ev gibi kapalı bir ortamda olmamak", "paranın azlı̆̆ldır", "asgari ücrettir", "bir insan karninı doyuramıyorsa, evi yoksa yoksuldur", "maddi anlamda sıkışı, maddi anlamda düşük olmak", "gelir düzeyi düşük, aile fert saylsı yüksek, geçimini zor sağlayan", "ekonomik olarak ihtiyaçlarını karşılayamamaktır", "insani standartlarda yaşayamamaktır", "maddi açıdan yetersizliktir", "bir insanın gereksinimlerini karşılayamamasıdır", "parasızlıktır", "bireyin hayatını sürdüreceği şeylere parasının yetmemesidir", "beslenme, barınma, giyinme gibi ihtiyaçlarını karşılayamamak, normal hayat standartlarının altında yaşam sürdürmek", "yoksulluk, insanın fuzuli ihtiyaçlarının dışında istediğini alamaması, sadece aç olmak, açıkta kalmak değil, canın bir şey 
istediğinde onu yapamamak", "maddi durumunda yeterli bir seviyeye ulaşamamak, yaşantısının alt seviyede olması, herkesin yaptı̆̆ şeyleri yapamamak", "geçim durumunun çok zor ve alt düzeyde olması", "ulaşım, ĕgitim, să̆llk hizmetlerinden faydalanamamaktır".

Ekonomik yaklaşımlar içinde değerlendirilebilecek olan mutlak yoksulluk ve göreli yoksulluk kavramlanı aslında yoksulluğun ölçülmesinde esas alınan kriterleri saptamakta ve böylece yoksulların sayısını bulmak için kullanılmaktadır.

Öğrencilerin yoksulluğu maddi ve manevi yoksulluk olarak sınıflandırdıkları görülmektedir. Öğrencilerin maddi yoksulluğun o kadar önemli olmadığını, asıl en zor olanın manevi yoksulluk olduğunu söylemeleri anlamlıdır. $\mathrm{Bu}$ yoksulluğa karşı direnç gösterdikleri ve kendilik değerlerini manevi açıdan zengin olmakla ilişkilendirdikleri anlamına gelmektedir. Çünkü maddi anlamda yoksulluğun insanın kendilik değerlerini zedelediği ögrencilerin "kişiye özgü" yoksulluk tanımlamalarında da görülmektedir: Yoksulluk yarım kalmak, her şeyi yarım yaşamaktır. Yoksul insan diğerlerini yüksek, kendini aşağı görmektedir. Bir şeylerden mahrumdur, yardıma muhtaçtır. Dış dünyadan soyutlanmış, yalnız kalmıştır. Yoksul insan bomboştur, iki tane cümleyi yan yana getirip konuşamamaktadır. Bir şeyi yapamaz, bir şeye engel olamaz. Yoksul kişide bir eksiklik olur. Sürekli bir sıkıntı içindedir. İnsanlar içinde yoksulluğundan dolayı mahcuptur, toplum içinde küçük düşmüştür, mutsuzdur. Öğrencilerin manevi yoksulluk tanımı; "manevi yoksulluk; insanın vicdandan, sevgiden, bilgiden, kültürden ve diğer insanların ilgi ve desteğinden mahrum olmasıdır", şeklinde ifade edilebilir.

Öğrencilerin öğrenci olarak deneyimledikleri yoksulluk halleri üzerine nitelemelerinden ise öğrenci yoksulluğu tanımlarına ulaşılmıştır. Öğrenci yoksulluğunun ulaşım ve gıda ihtiyaçlarını giderememe ve kamusal alanlar olarak da nitelenebilecek özellikle kafe başta olmak üzere çeşitle mekânlara gidememe, gidildiğinde ise parasızlık nedeniyle utanç duyma gibi konularda ağırlıklı olarak hissedildiği görülmektedir.

\subsection{2. Öğrencilerin Yoksulluk Deneyimleri}

Öğrencilerin yoksulluğa ilişkin deneyimleri öğrencilerin kendilerinin yaşadıkları yoksulluk deneyimleri ile diğer öğrencilerin yoksulluk deneyimlerine tanık olmaları biçiminde anlatılmıştır. Öğrencilerin gıdadan, barınmaya, ulaşımdan giyim ihtiyaçlarına dek sorun yaşadıkları görülmektedir. Bu tür sorunlarla zihinsel olarak da meşgul olmaktadırlar. Yoksulluk çeken öğrenciler için geçinmek önemli bir sorundur ve doğal olarak hayatlarının merkezinde yaşadıkları temel düşünme meseleleridir. Bu sorunları yok saymak ve başka ilgi alanlarına yönelmek o kadar da kolay olmamaktadır. Öğrencilerin, diğer öğrencilerin yoksulluk durumlarına ilişkin tanıklıkları da önem taşımaktadır. Buna göre tanık olunan durumlar; aç kalmaktan, tek tip beslenmeye; okula gelecek yol parası olmayan öğrenciden, hiçbir etkinliğe katılmayan öğrenciye ya da maddi olarak iyice yoksulluğa düşüldüğünde okul dışında yurttan çıkmayıp sürekli uyuyan öğrenciye; çalışmak zorunda olduğundan dersleri aksatan ve okulu uzatan öğrenciden, okulu donduran ya da okulu birakmak zorunda kalan öğrenciye dek değişmektedir. Öğrencilerin dikkat çeken tanıklıklarından biri de yoksul öğrencilerin sürekli aynı kıyafetleri giymesi, iyi giyinmemesi ya da giysileri nedeniyle alay konusu edilmelerine ilişkindir. Öğrencilerin bir diğer tanıklığı da aileleri zor durumda olduğu için kendisi sıkıntı yaşasa da çalışıp ailesine para gönderen öğrencilerin varlığıdır.

Bazı öğrenciler de yaşanan sıkıntı ya da yoksulluğun bir kısmının öğrencilerin gelirlerini idare etmeyi bilmemesinden ve fazla harcamalar yapmalarından kaynaklanabildiğine dikkat çekmişlerdir. Bunların yanı sıra katılımcı öğrencilerden ikisi yoksul öğrenciye tanık olmadığını; biri, küçük bir kesimin yoksulluk yaşıyor olabileceğini, bir diğeri de öğrencilerin durumunun normal olduğunu, kötü durumda olan bir öğrenciyi fark etmediğini ifade etmiştir.

\subsection{3. Öğrencilerin Yoksulluk Deneyimi Yaşamaya İlişkin Düşünceleri}

Yoksunluk duygusu yaşayıp yaşamadıkları sorusuna öğrencilerin 54'ü yoksunluk duygusu yaşadıkları, 46'sı ise yoksunluk duygusu yaşamadıkları yanıtını vermiştir. Yoksunluk duygusu yaşadıklarını ifade eden öğrencilerin ne tür yoksunluklar yaşadıkları üzerine ifadeleri de önem taşımaktadır. Öğrencilerin yoksunluk duygusu yaşadıkları konulara baktığımızda ciddi ekonomik yoksunluk yaşayan öğrencilerin yanı sıra, kendini geliştirebileceği bir takım kurslara gidememek, gezilere ve kültürel etkinliklere katılamamaktan dolayı yoksunluk yaşayan öğrenciler bulunmaktadır. Bunların dışında duygusal anlamda yoksunluk duyduklarını belirten öğrenciler, sayg1, empati, aileyle iletişim, özgüven ve dostluktan yana yoksunluk hissettiklerini ifade etmektedirler. Bu durumun sosyal sermayenin yetersizliğiyle de ilişkili olduğu söylenebilir. 


\subsection{4. Öğrencilerin Yaşam Koşullarını Diğer Öğrencilerle Kıyaslaması}

Öğrencilerin yaşam koşullarını diğer öğrencilerle kıyaslaması sonucunda öğrencilerin 51'inin durumunu orta düzeyde, 36'sının iyi düzeyde ve 13'ünün ise kötü düzeyde gördüğü ortaya çıkmıştır. Ancak bu görüşlerde de çelişkili durumlar olduğu söylenebilir. Özellikle durumunun orta düzeyde olduğunu düşünen öğrencilerin aslında bununla çoğunlukla orta sınıfta olmalarını kastetmedikleri sadece onlardan daha kötü durumda olan öğrencilerin varlığına dayanarak ve yine bir şükretme duygusuyla orta düzey yanıtını verdikleri görülmektedir.

Ekonomik açıdan daha rahat olan ve yaşam koşulları iyi olan öğrencilerin kendilerini iyi düzeyde görmelerinin yanı sıra, ekonomik açıdan sıkıntı çektikleri halde; yurtta değil kiraladıkları evde ya da ailelerinin yanında kaldıkları için, ailelerinin desteğini hissettikleri, istedikleri yiyeceği yiyebildikleri, sosyal oldukları, kendilerini geliştirebildikleri için ya da derslerde başarılı olup çevreye uyum sağlayabildikleri için de öğrenciler yaşam koşullarının daha iyi olduğunu düşünebilmektedirler.

\subsection{5. Öğrencilerin Kendilerinden Daha İyi Koşullarda Yaşayan Öğrencilere Yönelik Algısı}

Öğrencilerin kendilerinden daha iyi koşullarda yaşayan öğrencilere yönelik algıları da belli gruplandırmalara gidilebilecek farkl111klar göstermektedir. Bu gruplandırmalar, "kötü hissetmek", "kötü hissetmemek", "imrenmek, özenmek, heveslenmek", "klskanmak", "hiçbir şey hissetmemek" "olumlu özellikler atfetmek", "olumsuz özellikler atfetmek" ş̧eklinde sıralanabilir. Bazı öğrencilerin ise düşüncelerini ifade ederken "geleneksel mesellere ya da din temelli ifadelere başvurma" yolunu seçtikleri görülmektedir. Bunlardan birkaç örnek şöyledir:

"Allah daha çok versin diyorum" (Mehmet, Türk Dili ve Edebiyatı, 3. sınıf).

"Bir kitap okumuştum Keykavus'tan bir öğüt veriyor 'evladım kendinden üstündekileri düşünüp üzüleceğine kendinden altındakilere bak da mutluluk duy" benim şöyle bir yapım var ben kıyaslanmayı hiç sevmiyorum, bu böyleymiş, bu şöyleymiş, bu şunu yapmış, kıyaslamadım hiç" (Metin, Türkçe Öğretmenliği, 3. sınıf).

“Tabii öyle olmak istiyorsun ama Allah'ın verdiği de bu şükrediyorsun” (Hülya, Biyoloji, 4. sınıf).

"Nasıl diyeyim ben size, olabilir diyorum ben buyum biraz da kadermiş diyorum her şeyin hayırlısı diye düşünüyorum yani” (Ebru, İnşaat Mühendisliği, 3. sınıf).

Öğrencilerin ifadelerine bakıldığında kendisinden daha iyi koşullarda yaşayan öğrencilere baktıklarında "kendilerinde eksiklik hissetme" "iç kanama duygusu", "üzüntü, eziklik duyma", "kendisine ve ailesine acıma", "küçümsenme", "aşağılanma" gibi hisler içinde oldukları görülmektedir.

Necmi Erdoğan'a göre; yoksulları anlamak için yoksulların dahil olduğu veya dışlandığı siyasal ve kültürel süreçler, içlerinde yer aldıkları toplumsal hiyerarşiler ve iktidar konumları, kendilerine ve başkalarına dair temsilleri önem taşımaktadır (Erdoğan, 2002:9). Çalışmanın bu kısmında özellikle dezavantajlı öğrencilerin kendi koşullarına ilişkin sorgulamalarına dikkat çekmek istenmektedir. Kendilerini koşulları nedeni ile kötü hisseden öğrencilerin koşullarına ilişkin sorgulamaları kendilerinde bir eksiklik aramaya kadar varabilmektedir. Bunun yanı sıra koşulları daha iyi olan öğrencilerin kendilerinde "imrenmek, özenmek, heveslenmek, kıskanmak ya da çaba sarfetmek" hislerini yarattığını ifade eden öğrenciler de bulunmaktadır.

Öğrencilerin 23'ünün koşulları daha iyi olan öğrencilere olumsuz özellikler atfettikleri görülmektedir. Bunlar; "savurgan", "parayı çar çur eden", "sorumsuz", "bencil", "şımarık", "yozlaşmış yaşam sergileyen", "kendini üstün gören", "bize bakışı farklı olan", "kendini beğenmiş", "ukala", "maddiyatı önemseyen”, "ölümün, yoksulluğun, fakirliğin farkında olmadan ilerleyen", "elindeki koşulları değerlendiremeyen", "elindeki imkânları ezmeye yönelik kullanan", "kendini bilmez", "bilmişlik taslayan", "kendilerini bir şey sanan", "rahat", "aile korkusu olmayan", "hiçbir şeyi kafalarına takmayan".

\subsection{6. Öğrencilerin Kendilerinden Daha Kötü Koşullarda Yaşayan Öğrencilere Yönelik Algısı}

Öğrencilerin 29'unun kendinden daha kötü koşullarda yaşayan öğrencilere yardım etme hissi duydukları görülmektedir. Öğrencilerden bir kısmı da yardım etmek istediğini ancak kendi koşullarının da iyi olmadığını belirtmişlerdir. Burada dikkat çekici olan yoksulluğun bireysel olarak ele alınması, yoksulluk karşısındaki tepki ya da davranışın da "bireysel" olarak düşünülmesidir. Yoksulluk olgusu toplumla, toplumsallıkla birlikte düşünülmemektedir. Öğrencilerden bazıları ise koşulları daha kötü öğrencilerin onlarda "üzülmek, çok kötü hissetmek, acımak, vicdan azabı duymak, kendisini bencil bulmak, utanmak" duygularına yol açtığını 
KETE TEPE, Nazmiye ve ÖZER, Yavuz - Üniversite Öğrencilerinin Yoksulluk Algısı Üzerine Nitel Bir Araştırma

söylemektedirler. Öğrencilerin sekizi ise koşulları daha kötü öğrencilerin onlarda "anlamaya çalışmak, paylaşmak ve dayanışmak" duygularına yol açtığını ifade etmektedirler. Öğrencilerden ikisi yoksullara olumlu özellik atfetmektedirler: Öğrencilerden biri "koşulları kötü olan kişilerin daha iyi insanlar olduğunu" bir diğeri de "bu insanlar arasından kötü insanlar çıkmadığını" ifade etmiştir.

\subsection{7. Öğrencilerin Yoksul Olmanın Dezavantajları Hakkındaki Düşünceleri}

Öğrencilerin yoksulluğun ne tür dezavantajlara neden olduğu sorusuna verdikleri yanıtlar da farklılaşmaktadır. Kimi öğrenciler imkânların azlığ̣ nedeniyle gidilemeyen dershaneden, kurstan söz ederken, kimi öğrenciler yoksul insanın çekingenliğinden, içe kapanıklığından, özgüven eksikliğinden söz etmektedirler. Kendi deneyimlerinden söz eden öğrenciler de bulunmaktadır. Öğrencilerden bazıları ise yoksulluğun dezavantaj değil kişiyi daha hırslı ve mücadeleci yapan bir durum olduğu ve avantaja da dönüşebileceğini söylemektedirler.

Türk Dili ve Edebiyatı Bölümü öğrencisi Teoman, yoksulluktan bir geri kalmışlık durumu olarak söz etmektedir. Teoman, yoksul bir ailenin sunabileceği olanakların kısıtlılığının insanın konuşmasına bile yansıdığını ve bir şeylerin eksikliğiyle çabalamanın kahramanlık olduğunu söylemektedir. Ona göre; büyük bir eksiklik hisseder yoksul insan. Aynı zamanda zenginler ve yoksullar mekânsal olarak da ayrışmıştır.

İktisat Bölümü öğrencisi Menekşe yoksulların hayata atılmaya çekindiğini söylemektedir. Menekşe’ye göre; "yoksulluğun insanın üzerine yapıştırdı̆̆ı etiket onu her şeyden, arkadaş ortamındaki bir sözden bile, yoksun bırakmaktadır". Sosyoloji Bölümü öğrencisi Orhan ise; sınıflar arası dikey geçiş olsa da bunun sınırlı olduğunu söylemektedir. Ona göre; üst sınıftan bir insanın her türlü imkânı varken, yoksul bir insanın tek seçim şansı bir işe girip çalışarak hayatta kalabilmektir. Böyle bir durumda da yoksullar için imkânlardan bahsedilemez.

Gıda Mühendisliği öğrencisi Çağatay’a göre de; “yoksulların çoğu yeteneklerini gösterememektedir. Çünkü bunun için imkânları yoktur. Yoksul insan bastırllmıştır". Uluslararası Ticaret ve Finansman Bölümü öğrencisi Bekir, sadece okumanın, üniversite bitirmenin hatta yüksek lisans yapmanın yeterli olmadığına dikkat çekmektedir. Bekir; "Bir şeyi görmek önemli, görebilmek önemli fakat imkân olmadığı için buradan kimse çıklp gidip göremiyor. Açıkçası okumak bir yere kadar. Bu şartları oluşturamadiğımız zaman mutlaka kendimizi geliştirmekte sıkıntı çekiyoruz. Bu da yoksullukla ilgili", demektedir. Bu sözler; farklı ortamları deneyimlemeyi, gezip görmeyi, toplumsal ilişkilerin zenginliğini, toplumsal hayata etkin olarak katılmayı, imkânların genişliğiyle bir tür hareket ve seçim özgürlügünün olmasını akla getirmektedir. Büro Yönetimi ve Yönetici Asistanlığı Programı öğrencisi Çağan yoksul bir öğrencinin istediği gibi hareket edemediğini söylemektedir. Sınıf Öğretmenliği öğrencisi Gülbeyaz ise insanın parası olduğunda her türlü şeyi yapabildiğini, paranın her şey olmadığını ama hayatın içinde her şeye dönüştüğünü söylemektedir. Bu durumda parasızlığın aynı zamanda seçeneksizliğe dönüştüğü söylenebilir, yapılabilecek şeyleri kısıtlıyor olması insanı da kısttlaması anlamına gelmektedir.

Emre ve Ayşen, yoksulluktan kaynaklı olarak insanların iyi eğitim alamayabileceğini ve bunun ileride daha düşük gelirli işlerde çalışmak anlamına geldiğini söylemektedirler. Radyo ve Televizyon Programcılığı Programı öğrencisi Rüya'nın bu konudaki görüş ve deneyimleri de oldukça dikkat çekicidir. Yoksul öğrencilerde çekingenlik olduğunu, birçok etkinlikten mahrum kaldığını söyleyen Rüya, öğrencilerin yoksulları dışladığını, kendi gelir düzeylerine sahip öğrencilerle arkadaşlık etmeyi seçtiğini, yanlış olsa da bunu kendisinin de yaptığını ifade etmektedir.

Öğrenciler yoksulluğun kişi üzerinde yarattı̆̆ı dezavantajlardan "kendini yetersiz hissetme", "yapamama duygusu", "özgüven eksikliği", "bir sözden bile yoksun kalma", "kendini dışa kapatma", "sosyal hayata katılamama", "stresli ve sinirli olma", "erteleme", "vazgeçme", "kisıtlanma", "çekingenlik", "geç kalma, gecikerek yaşama" üzerinde durmaktadırlar.

Öğrencilerden bir kısmı ise yoksulluğun öğrencilerde neden olduğu dezavantajlar olarak kurslara, gezilere katılamamak üzerinde durmaktadırlar. Öğrencilerden 11'i ise yoksulluğun dezavantaj olmadığını, avantaja dönüşebileceğini söylemektedirler. Bu öğrenciler yoksul insanların daha mücadeleci ve hırslı olduğunu ya da insanın isterse her koşulda başarılı olabileceğini ifade etmişlerdir.

\subsection{8. Öğrencilerin Toplumun Yoksulluğa ve Yoksullara Bakışı Konusundaki Algıları}

Toplumun yoksullara ve yoksulluğa bakışı konusunda öğrencilerin düşünce ve deneyimleri oldukça önemli sonuçlar ortaya koymaktadır. Ağırlıklı olarak öne çıkan toplumsal algı yoksulların "küçümsenen, aşağılanan, dışlanan, görmezlikten gelinen, ikinci sinıf, alt seviyeden insanlar" oldukları yönündedir. Toplum onları görmezlikten gelmekte, dışlamakta ve ezmektedir. Aynı zamanda "yoksullardan uzak durulmakta", onlarla 
"konuşulmamaktadır". İlk olarak, öğrencilerin yoksulların toplum tarafından olumsuzlandığını dile getirdikleri ifadelerden bazı örnekler verelim:

"Yoksul bir kişi kendini ülkeden dışlanmış olarak görüyor" (Fidan, İç Mimarlık ve Çevre Tasarımı)

'Parasız insan şerefsiz, insandır.'

"Birinci sınıftayken (...) cafe var, orada çalışıyordum ben hatta bir arkadaşım daha vardı fakülteden. Garsonluk yapıyorduk. Onun sahibi derdi: Parasız insan șerefsiz insandır. Yani genelde çok yoksul insan toplumda çok arka sıralara itiliyor" (Hasan, Tıp Fakültesi)

“Yoksullar çalışmıyor” (Cihat, Tarih Bölümü)

Öğrencilerin toplumun ve kendilerinin yoksullara bakışına yönelik algıları belli bir çeşitliliği de yansıtmaktadır. Bunun ilk akla gelen nedenleri olarak yoksulluğun heterojen olması (tek bir yoksulluk biçimi yoktur) ve toplumsal kesimlerin sınıf, mekân ve deneyimlerinin yoksullara bakışını değiştirebilmesi söylenebilir. Şimdi bu özgün durumlara yer verilecektir:

“Yoksulluk normal görülï̈yor” (Zeynep, Biyoloji)

“İnsanlar yoksulluğa alışmışlar”

Uluslararası Ticaret ve Finansman 4. sınıf öğrencisi Bekir, eskiden insanların yoksul olduğunda haklarını aradığını günümüzde ise insanların yoksulluğa alıştığını söylemektedir. Bekir toplumda yoksullara acımanın yoksulluğun ortadan kaldırılması yönünde bir çabaya neden olmadığını, duygusallık düzeyinde kaldığını belirtmektedir. Bekir'e göre, toplumda yoksulluğun kader olduğu ve yoksulların çalışmadığı gibi görüşler hâkimdir;

"Şimdi biz yeni nesil olduğumuz için hani eski nesilden de babalarımızdan dedelerimizden duyduğumuz eskiden insanlar yoksul olduğu zaman haklarını arıyorlarmış. Şimdi tam tersi görüyorum. İnsanlar yoksulluğa alışmışlar. Bu ülkede insanlar yoksulluğa alışmış. Sanki hoşlarına gidiyor gibi. Hani yoksullukla ilgili iyileştirme gibi bir düşünce insanların iyileştirme çabast yok. Tamamen yoksulluğa alışmış durumdalar. Muhtaç oldukları için de sürekli aynı şeyde devam ediyor. O yüzden yoksulluk çok büyük sorun değilmiş gibi görünüyor insanlar için".

Bekir'in ifadesi görüştüğümüz 100 öğrenci içerisinde yoksulluğa "hak temelli bir baklşın" neredeyse tek örneğini oluşturmaktadır. Bekir, yoksul olmayan insanlar için ise yoksuların her zaman firsat olduğunu söylemektedir. Ona göre, yoksullar ucuz işgücü olduklarından bu her zaman belli bir kesimin çıkarına olacaktır:

“Asgari ücret sadece temel ihtiyaçların giderilmesiyle alakall, bu yanlış” (Zafer, Seyahat İşletmeciliği Bölümü)

Seyahat İşletmeciliği, 3. sınıf öğrencisi Zafer yoksulluğun sadece karın doyurmakla giderilemeyeceğini söylemekte, insanların kültürel ve siyasal olarak da etkin olmalarının gerektiğini söylemektedir. Bu nedenle asgari ücretin sadece temel ihtiyaçlar göz önünde tutularak hesaplanması yanlıştır.

"Bence, dışarıda yatanlar, onlar yoksul”

Hülya (Biyoloji Bölümü) ve Fikret'e göre (İnşaat Mühendisliği) asıl yoksulluk sokakta yaşayan evsiz insanlar ve mülteci kamplarındaki insanların yaşadıklarıdır.

“Benim köyümde yoksulluk diye kavram yoktur”

İnşaat Mühendisliği öğrencisi Yaşar, köylerinde yoksulluk kavramının kabul edilmediğini ve sürekli çalışmaya önem verildiğini, çocukların zorla da olsa çalıştırıldığını söylemektedir.

\section{"Herkes isyan ediyor, harekete geçmek yerine devlete suç attyor"}

Tıp Fakültesi, 6. sınıf öğrencisi Kadir herkesin isyan ettiğini harekete geçmek yerine devleti ve ailesini suçladığını söylemektedir. Başka sorulara verdiği yanıtlarda da kendisinin de yoksul olduğunu belirten Kadir "çalışmıyorsa yoksullar ölsün" ifadesini kullanmıştır. Kadir'in neoliberal ideolojinin yoksulluk anlayışını içselleştirdiği görülmektedir. Yoksulluk kişinin bireysel sorunudur. Yoksullar girişimci olmalı, çalışmalı ve çözüm üretmelidir:

“Yoksullar kendilerinden soğutuyor”. 
İktisat, 4. sınıf öğrencisi Menekşe’ye göre günümüzde yoksullar dışlanmamaktadır. Zenginler ve yoksullar arasındaki mesafenin nedeni yoksulların kendilerini etiketleyerek kendilerinden soğutmalarıdır.

"Yoksulluk, bitmişlik, tükenmişlik sendromu gibi bir şey”

Tarih Bölümü, 4. sınıf öğrencisi, Özge kendi ailesinden iki örnek vermektedir. Amcalarının yoksulluğu hayatın bittiği, karşısında hiçbir şey yapılamayan bir çaresizlik hâli olarak yaşadığını adeta bitmişlik, tükenmişlik sendromu gibi bir şey olarak algıladığını, yaşadığını söylemektedir. Ancak teyzesinin çok sıkıntılı durumlar yaşasa da yoksulluğu böyle görmediği için şimdi koşullarının çok iyi olduğunu belirtmiştir. Özge'ye göre, sabretmek her şeyin çözümüdür.

“Yoksullara pek ayrımcıllk yapılmaz” (Ertunç, Büro Yönetimi ve Yönetici Asistanlığı)

"Yoksulluk işini firsata çevirenler var"

İnşaat Mühendisliği, 2. sınıf öğrencisi Esra'ya göre yoksul olmadığı halde yoksulluğu firsata çeviren insanlar olduğundan yardım isteyenlere önyargılı davranılmakta ve güvenilmemektedir:

\section{“Yoksulun halini ancak yoksulluk yaşamış insan anlar"}

Öğrencilerden bir kısmı yoksulluğa yoksulların gözüyle bakarak yoksulluğa ilişkin görüşlerini açıklamışlardır. Mesut'a göre yoksul insanın halini daha önce yoksulluk çekmemiş insan anlayamamaktadır. Ayhan, kendi ailesinin geçmişte yoksulluğu yaşamış bir aile olarak yoksullara kötü gözle bakmadığını ancak çevrelerinde yoksullara kötü gözle bakmayan bir çevre olduğunu söyleyemeyeceğini ifade etmiştir. Çağan kendi köyünde yoksulluğu büyük dert olarak yaşayan insanlar olduğunu söylemektedir. Cemile'ye göre ise yoksulları kimse umursamamaktadir.

\section{"Yoksul insanlar daha iyi olabilme ümidi içinde değiller"}

Gülcan'ın yoksul insanlara yönelik izlenimleri de dikkate değerdir. Ona göre, yoksullar daha iyi olabilme ümidini yitirmiş daha kötü olmamak için çabalamaktadırlar. Yoksullar açısından 'bıçak kemiğe dayanmış' durumdadır. Ancak toplum yoksullara iyi gözle bakmamakta, büyük şehirlerde yoksullara ucube gibi bak1lmaktadır:

\section{Yoksullar da düşünüyor: Biz neden böyleyiz?}

Aslı, yoksulların da neden bu durumda olduklarını düşündüklerini ve çalıştıkları halde onlarda neden az, zenginlerde neden çok olduğunu sorguladıklarını söylemektedir. Sorgulamasını bir çiftçi ve bir holding sahibini karşılaştırarak yapmaktadır. Mesele çalışmaksa çiftçi de çok fazla çalışmakta ancak az kazanabilmektedir. Aslı her ne kadar çözümleyemese de bir dengesizlik olduğunu ifade etmektedir:

\section{"Yoksullar kendilerini stradan görüyorlar"}

Baran, yoksul çevrelerde yoksulların sıradan insanlar olarak görüldüğünü söylemektedir, yani yoksullar kendilerini sıradan, zenginleri sıra dışı olarak değerlendirmektedir.

\section{“Kim yoksul, kim değil, ayırt edilemiyor"}

Sosyoloji öğrencisi Hale'ye göre, günümüzde kimin yoksul olduğu kimin olmadığını ayırt etmek zorlaşmıştır. Ona göre bunun nedeni insanların gelirlerini kullanma biçimlerinin farklı olmasıdır. Bunu bir örnekle açıklamakta örneğin üstü başına özen göstermeyen birinin dış görünümüyle yoksul olduğunun düşünülebildiğini ancak o kişinin gelirini mal mülk edinmeye harcadığını söylemektedir.

\section{"Yoksullara yardım ediliyor"}

Öğrencilerden 13'ü toplumda yoksullara yardım edildiğini, böyle bir eğilim ve isteğin olduğunu söylemektedirler.

\section{"Yoksullar bayramlarda hatırlantyor"}

Ferhat'a göre, yoksullar Ramazan ve Kurban bayramlarında hatırlanırken ve bayramlarda onlara yardım edilirken diğer zamanlarda görmezlikten gelinmektedir:

\section{“Gözlerine soka soka yardım ediliyor”}

Ayşen'e göre yapılan yardımlar bir gösteriş içinde insanların gözlerine sokularak yapılmaktadır: 
"Para yetirememe ya da düzenli harcamadiğından dolayı yani düşüncesiz harcadiğından dolayı insanlar sıkıntı çekiyor olabilir ama toplumda hep bir yardım edelim tavrı hâkim. Hani gözlerine soka soka yardım etmek vardır ya Türkiye'de bu böyle" (Ayşen, Gıda Teknolojisi Programı, 2. sinif).

\section{"Sözde yardım"}

Öğrencilerin 11'i ise insanların yardım etmekten söz ettiğini ancak gerçekten yardım etmediğini düşünmektedirler.

\section{"Yoksullar hayal unsurları olarak görülüyorlar."}

"Hayal unsurlarl olarak görülüyor. Hep yardım ederiz falan diyorlar. Ama hep lafta kallyor. Kimse işleve geçirmiyor o sözleri" (Aydın, Radyo ve Televizyon Programcılığı Programı).

Öğrencilerin yaklaşık yüzde 30'unun yoksullara yardım edilmesi ve yardım edilmemesi üzerinde durdukları görülmektedir. Ancak burada da yardımın bireysel düzeyde ele alındığı koşulları daha iyi olanların ve zenginlerin yardımının ima edildiği görülmektedir. Yoksulluk probleminin toplumsal bir problem olarak ele alınmadığı söylenebilir. Bu aynı zamanda öğrencilerin yoksulluğun çözüm yolları olarak da bireysel çabaları ve yardımları düşündükleri şeklinde yorumlanabilir.

\subsection{Farkındalıklar, Öneriler ve Çözümler}

Bu kısımda öğrencilerin yoksulluğun nedenleri hakkındaki görüşleri ve öğrenci yoksulluğu hakkındaki çözüm önerileri incelenmektedir. Burada özellikle belirtilmesi gereken ve üzerinde düşünülmesi gereken nokta öğrencilerin yoksulluğun nedenleri sorusunu yanıtlamakta zorlanmalarıdır. Yine çözüm önerileri konusunda da öğrencilerin zorlandıkları söylenebilir. Bu bölümde öğrencilerin bu konular üzerine görüşlerine yer verilirken bir yandan bu konularda fikir üretmekte zorlanmalarının olası nedenleri üzerinde de durulmaktadır.

\subsection{1. Öğrencilerin Yoksulluğun Nedenleri Hakkındaki Görüşleri}

Öğrencilerin yoksulluğun nedenleri sorusuna verdikleri yanıtlardan oluşan kategoriler şunlardır;

- Yoksulluğun nedeni içine doğduğun ailenin yoksul ya da zengin olmasıdır, bu da şansa, kadere bağlıdır.

- Yoksulluğun nedeni bireyin kendisidir: Yoksullar çalışmadıkları için tembelliklerinden dolayı yoksuldurlar.

- Yoksulluğun nedeni dini referanslarla açıklanabilir.

- Yoksulluğun nedeni eğitimsizliktir.

- Yoksulluk zengin insanların bencilliklerinden kaynaklanmaktadır.

- Yoksulluğun nedeni emek sermaye çelişkisidir (kapitalizm, emperyalizm, özel mülkiyet, işsizlik).

Görüldüğü üzere; öğrencilerin bir kısmına göre yoksulluğun nedeni ailenin yoksul olmasıdır ve geçmişten geleceğe doğru bu yoksulluk aktarılmaktadır. Aslında bu yoksulluğun nedeni olmaktan çok yoksulluğun bir kısırdöngü olarak yaşanmasını açıklayan bir durumdur. Aynı zamanda yoksulluğun bir kader olduğu düşüncesini de içermektedir. Yoksulluğun nedeninin ailenin geçmişten bugüne getirdiği ekonomik koşulların yetersizliği olarak göstermek bunun aynı zamanda değiştirilemez bir süreç olarak görüldüğünü düşündürmektedir. Bununla birlikte yoksulluğun nedenini ailenin ekonomik düzeyine bağlarken aile büyüklerinin akıllıca davranıp, doğru kararlar almadıkları ve yeterince çaba göstermediklerini ifade eden öğrenciler aileyi bu nedenle örtük biçimde de olsa suçlamaktadırlar.

Öğrencilerin 30'undan fazlasının yoksulluğun nedenlerini yoksulların kendisine bağladıkları görülmektedir. Yoksullar, tembel oldukları için çalışmadıkları, çabalamadıkları ya da iş beğenmedikleri için yoksuldurlar gibi yoksulları suçlayan görüşlerin öğrencilerin önemli bir kesiminde yaygın olduğu söylenebilir.

Öğrencilerin bazıları ise yoksulluğun nedenini açıklarken bunu dini inançları çerçevesinde ele almaktadırlar. İslam dininin zekât aracilığıla yoksullara yardım edilmesini istemesine rağmen insanlar bu görevi yerine getirmemektedirler görüşü olduğu gibi, yoksulluğun Allah tarafından verilen bir kader olduğu düşüncesi yoksulluğun doğallaştırılması anlamına gelmektedir. 
Öğrencilerin 13'ü yoksulluğun nedeni olarak eğitimi göstermektedirler. Yani insanların aldıkları eğitim düzeyi yükseldikçe gelirleri artmakta ve yoksulluktan kurtulabilmektedirler. Buna göre öğrencilerin bir kesiminin eğitimi sınıf atlamada önemli bir araç olarak gördükleri söylenebilir.

Öğrencilerin 9'u insanların bencilliği nedeniyle yoksulluk olduğunu düşünmektedir. Öğrencilerin bir kesimi insanların hırs, açgözlülük gibi doğalarından kaynaklanan özellikleri nedeniyle yoksulluğun olduğunu söylemektedirler.

Öğrencilerin sadece 23'ünün yoksulluğun yapısal nedenleri olabileceğinden söz ettikleri görülmektedir. Ancak öğrencilerin bir kesiminin yaşam koşullarını da doğrudan etkileyen yoksulluk gibi bir problemin toplumsal yapıyla ilişkisini kuramaması düşündürücüdür. Bu noktada öğrencilerin özellikle sosyoloji, ekonomi, felsefe, etik, mantık, düşünce eğitimi, insan hakları, vatandaşlık, sosyal politika, gibi bazı temel formasyanları eğitim süreçleri boyunca kazanamamış oldukları dikkate alınmalıdır. Bu konularda formasyanlar edinmeleri her birey için önem taşıdığı gibi özellikle dezavantajı öğrencilerin yaşam koşulları hakkında farkındalıklarının artması ve etkin bireyler olarak bu koşullara çözüm üretilmesine katkı sağlamaları bakımından özel bir önem de taşımaktadır. Çünkü herhangi bir konuda toplumsal problem yaşayan bir kesimin düşünümselliği hakiki çözümler üretmek bakımından önem taşımaktadır.

\subsection{2. Öğrencilerin Öğrenci Yoksulluğu Hakkındaki Çözüm Önerileri}

Katılımcıların öğrenci yoksulluğu hakkındaki çözümlere yönelik düşünce ve önerileri şu şekilde özetlenebilir;

- Her şey ekonomi değildir, gençlere daha fazla yatırım yapılmalıdır.

- Öğrencilerin kredi ve bursları arttırılmalıdır. Bursun kesilmesi tehdidi olmamalıdır çünkü dersin alttan alınması koşullardan dolayı olabilmektedir.

- Öğrencilere özelikle yarı zamanlı iş imkânı sağlanmalıdır. Çalışma saatleri öğrencinin derslere girmesine imkân tanıyacak şekilde düzenlenmeli ve ücretler piyasadan düşük tutulmamalıdır.

- Öğrencilerin kendilerini geliştirebilmeleri için ücretsiz kurslar sağlanmalıdır.

- Yurtların arttırılması gerekmektedir. Yurt kapasiteleri yeterli olmadığından öğrenciler ev kiralamak zorunda kalmakta yüksek kiralara kötü evlerde yaşamak zorunda kalmaktadırlar.

- Kredilerin okul bitince geri ödenmesi konusu da öğrenciler için kaygı konusudur. Okul bitince iş garantisi de olmadığından öğrenciler baskı ve karamsarlık yaşamaktadırlar.

- Öğrenciler daha fazla desteklenmelidir; çalışma ve burs olanaklarının arttırılması ve indirimli barınakların sağlanmasıyla bu gerçekleştirilebilir.

- Öğrenciler için belediye, üniversite ve özel kişilerin ortaklığında öğrenci köyü ya da kasabası gibi projelerle öğrencilerin barınma sorunlarına çözümler üretilebilir. Burada amaç rant elde etmek değil öğrenciler için ucuz, sağlıklı barınma imkânlarının yaratılması olmalıdır.

- Öğrencilere burs ve kredi verilmesi konusunda bunun hakkaniyetli bir şekilde yapılmadığına dair öğrencilerde yaygın bir kanaat bulunmaktadır. Bu konuda daha şeffaf ve açık kriterlerin olması bu şüpheleri giderecektir.

- Geri ödemeli kredilerin isteyen her öğrenciye verilmesi sağlanmalıdır.

- Kredi ve Yurtlar Kurumu'na bağlı devlet yurtlarının kapasiteleri arttırılarak bu yurtlardan isteyen herkesin yararlanması sağlanmalıdır.

- Sosyal aktiviteler arttırılarak sosyal çevrenin oluşması sağlanmalıdır.

Öğrencilerin yoksulluğa ilişkin çözüm önerilerine baktığımızda makul ve gerçekçi beklenti ve öneriler olduğu söylenebilir. Ancak burada belirtilen öneriler dikkate alınıp çözüm üretilmesi gerekmektedir. Ayrıca burada ifade edilen çözüm önerilerinin neredeyse tamamı ekonomik destekle ilgilidir. Oysa çalışmanın başından beri savunduğumuz gibi dezavantajlı öğrencilerin ekonomik sermayeleri kadar sosyal ve kültürel sermayelerinin arttırılması için de destek ve çalışmalara ihtiyaç bulunmaktadır. 


\section{SONUÇ}

$\mathrm{Bu}$ çalışma, üniversite öğrencilerinin sosyo-ekonomik koşullarından yoksulluk tanımlarına, öğrenim hayatları boyunca gözlemledikleri ve deneyimledikleri yoksunluklardan, bu yoksunlukların onlarda yarattığı duygu ve düşüncelere, toplumda yoksulların nasıl görüldüğüne ilişkin fikirlerinden, yoksulluğun nedenleri hakkındaki görüşlerine ve öğrenci yoksulluğuna yönelik çözüm önerilerine dek üniversite öğrencilerinin yoksulluk algısını tasvir ediyor, betimliyor. Nitel araştırmanın bir özelliği olan bu açıklama ve betimlemeler sonuç bölümünde özetlenmeyecek bir yapıya ve zenginliğe sahip. Ancak, tıpkı öğrencilerle dersliklerde, kampüste, öğrenci evlerinde sorular soran, konuşan ve dinleyen araştırmacının bir etkileşimli diyalog olan bu deneyim sonunda değişmesi gibi, bu makaleyi dikkatle okuyan kişilerin de üniversite öğrencilerine bakışında bir değişim olacağı umulabilir. Bu değişimin bir farkındalık yaratacağı, bu farkındalıkla öğrencilerin yaşamı, düşünce dünyası, ekonomik, toplumsal, kültürel, psikolojik vb. sorunlarına bireysel ya da kurumsal düzeyde bir duyarlılık geliştirilebilmesinde küçük de olsa bir katkı sağlayacağı düşünülmektedir.

Üniversite öğrencilerinin yoksulluk deneyimleri ile yoksulluk algılarına yönelik böyle bir çalışmada gençlik politikalarından söz edilmesinin nedeni yoksulluk ve yoksunluklar yaşayan dezavantajlı öğrenciler için üretilecek çözümlerin ancak bir gençlik politikaları perspektifi çerçevesinde üretilmesinin gerekli ve önemli olmasidir.

Gençliğin güçlendirilmesi prensibi içinde gençlerin toplumsal hayata katılabilmeleri için yapabilirliklerinin arttırılması üzerinde durulmuştur. Ahmet İnsel'e göre, kapasite ya da yapabilirlik (capability) kavramı, Amartya Sen'in çalışmalarında öne çıkardığı bir kavramdır. Bu kavram onurlu ve anlamlı bir yaşam için insanların haklarının olması, bu haklarını bilmesi ve haklarına ulaşabilmesi ile hak talep edebilecek yetenekleri olması olarak özetlenebilir (İnsel, 2000'den akt.: Kurtaran vd., 2008:11).

Hatırlanacağı üzere bu çalışmanın kuramsal kısmında yoksulluk, Amartya Sen'in geliştirdiği kapasite yaklaşımı açısından ele alınmıştır. Kalkınma, özgürlük, insani gelişme, insani yoksulluk ve insan hakları kavramlarıyla ilişkili olan kapasite yaklaşımı yoksulluğu maddi olanaklardan yoksunluk yanında kapasitelerden yoksunluk olarak tanımlamaktadır. Yaklaşımın özünü bir insanın yapmaya ve olmaya değer verdiği şeyler oluşturmaktadır. Bir başka ifadeyle, kapasite yaklaşımı, toplumu oluşturan bireylerin ne yapabilecekleri ve ne olabilecekleri anlamında kapasitelerine odaklanan bir yaklaşımdır. Bu yaklaşım, yoksulluğun çok boyutlu özelliğinin dikkate alınmasını sağladığı gibi yoksullukla mücadelede maddi kaynaklar yanında sosyal, kültürel kaynakların da etkili olabileceğini vurgulamaktadır. Bu noktada öğrencilerin yoksulluklarının sadece mutlak yoksulluk ya da ekonomik yoksulluk olarak görülerek onlara sadece maddi olanaklar sağlanmasının yeterli olmadığı dile getirilmiştir. Öğrenci yoksulluğunun farklı boyutları göz önünde tutularak onların yaşam koşullarını geliştirecek, ekonomik sermayelerinin yanında sosyal ve kültürel sermayelerini de geliştirebilecek deneyimleri yaşayacakları etkinlikler, düzenlemeler de gerekmektedir. Ahmet İnsel'in Amartya Sen'den hareketle yaptığı yapabilirlik (kapasite) tanımının, projenin bulgularından en önemli ve dikkat çekici olan şu sonuçla da anlamlı bir ilişkisi olduğunu vurgulamak gerekmektedir.

Araştırma bulguları sonucu ortaya çıkan tüm kategoriler ve öğrencilerin görüşleri dikkatle incelendiğinde ögrencilerin çoğunun yoksulluğa bakışının bireyci görüşleri yansıttığı söylenebilir. Bir diğer ifadeyle, öğrencilerin çoğunun neoliberalizmin yoksulluk anlayışını içselleştirdiği görülmektedir. Buna göre yoksulluk bireyin kendi suçudur ve sorununa çözüm üretmek de bireyin kendi sorumluluğundadır. Öğrenciler tarafindan yoksulluğun toplumsal bir olgu olarak tahayyül edilmediği ve öğrencilerin insanların vatandaşlar olarak bir takım ekonomik ve sosyal hakları olduğu bilgisinden habersiz olduğu görülmektedir. $\mathrm{Bu}$ ise acilen çözüm üretilmesi gereken ciddi bir meseledir. Yoksulluk olgusu, yoksulluktan olumsuz etkilenen çeşitli toplumsal kesimlerden oluşan geniş bir kitlenin yoksulluğa hak temelli bir bakışı olmadan gerçek anlamda çözümlenemez. Çünkü hak ve özgürlük temelli bir yaklaşım çerçevesinde problemin tüm boyutlarıyla bizzat yaşayanlarca dile getirilmesi problemlerin toplumun bütünü tarafından görünür olması ve daha etkin çözümler üretilmesine imkân sağlayacaktır.

Gençlik, hayatın en üretken olunabilecek bir evresidir. Çalışmanın kuramsal ve kavramsal çerçevesinde açıklanan habitus kavramı göstermektedir ki; bireyin yetersiz ekonomik, sosyal ve kültürel hayat koşulları içinde olması, onun; fikir, düşünce, davranış ve hayata katılımını belli kalıplar ve sınırlara hapsetmektedir. Bu durum ise karşımıza "yapabilirlik" sorununu çıkarmaktadır. Birey kendisine küçük hedefler belirlemekte, daha ötesini yapabileceğini hayal dahi edememektedir. Bu ise geniş bir gençlik kesiminin enerjisinin, yaratıcılığının ve yapabilirliğinin heba edilmesi anlamına gelmektedir. 
KETE TEPE, Nazmiye ve ÖZER, Yavuz - Üniversite Öğrencilerinin Yoksulluk Algısı Üzerine Nitel Bir Araştırma

Üniversite öğrencileriyle yapılan görüşmeler öğrencilerin maddi kaynaklar yanında, kendilerini ifade etmekten, değer verildiğini hissetmekten yana yoksunluk yaşadıklarını göstermektedir. Öğrencilerin gündelik yaşamının çoğunlukla okul ile ev ya da yurt arasında geçtiği; toplumsal hayata katılımda ve kültürel etkinlikler konusunda kısıtlı imkânlara, alışkanlıklara ve deneyimlere sahip oldukları görülmektedir. Öğrencilerin kendilerine kurmak istedikleri hayatın iş, evlilik, ev ve araba sahibi olmakla sınırlı olması özellikle düşündürücüdür. Aslında öğrenci yoksulluğu bilinen ama üzerinde kuramsal, kavramsal bir derinlikle tartış1lmayan, yeterli alan araştırması yapılmamış bir olgudur. Bu çalışmanın metropollerdeki özel ve devlet üniversitelerinde de tekrarlanması önerilmekte, bu çalışmada ulaşılan bulgularla benzerlik ve farklılıkların karşılaştırılmasına ihtiyaç bulunmaktadir.

\section{KAYNAKÇA}

ARIKAN, Rauf (2017), Araştırma Yöntem ve Teknikleri, Nobel Akademik Yayıncılık, Ankara, 3.Baskı.

ARKONAÇ, Sibel Ayşen (2014), Psikolojide Söz ve Anlam Analizi, Ayrıntı Yayınları, İstanbul.

AVCI, Özlem (2012), İstanbul'da Dindar Üniversite Gençliği, İki Dünya Arasında, İletişim Yayınları, İstanbul.

BAYHAN, Vehbi (1997), Üniversite Gençliğinde Anomi ve Yabancılaşma, T. C. Kültür Bakanlığı Yayınları, Ankara.

BOURDIEU, Pierre (1977), Outline of a Theory of Practice, Cambridge University Press, Cambridge.

BOURDIEU, Pierre (1984), Distinction: A Social Critique of the Judgement of Taste, Harvard University Press, Cambridge - Mass.

BOURDIEU, Pierre (1990), The Logic of Practice, Stanford University Press, Stanford.

BOURDIEU, Pierre ve PASSERON, Jean-Claude (2015), Vârisler Öğrenciler ve Kültür (Çev. Levent Ünsaldı ve Aslı Sümer), Heretik Yayınları, Ankara.

DENIZ, A. Çağlar (2014), "Öğrenci İşi" Üniversite Öğrencilerinin Gündelik Hayatı: İstanbul Örneği, İletişim Yayınları, İstanbul.

ERDOĞAN, Necmi (2002), Yoksulluk Hâlleri, Türkiye'de Kent Yoksulluğunun Toplumsal Görünümleri, Demokrasi Kitaplığ 1 Yayınevi, İstanbul.

EUROPEAN UNION (2011), European Commission Youth in Action Programme Guide, European Union, https://ec.europa.eu/assets/eac/youth/tools/documents/programme-guide-2011_en.pdf (Erişim Tarihi: 21.02.2011).

FURLONG, Andy (2013), Youth Studies, An Introduction, Routledge, New York.

HEINZ, Walter Richard (2009), "Youth Transitions in An Age of Uncertainty", Handbook of Youth And Young Adulthood: New Perspectives And Agendas (Ed. Andy Furlong), Routledge, Abingdon.

İDEMEN, Beril (2008), "Sosyal Köken, Habitus ve Ë̆itim: Pierre Bourdieu'nun Yeniden-Üretim Kavramı", Türkiye'de Gençlik Çalışması ve Politikaları (Der. Nurhan Yentürk, Yörük Kurtaran, Gülesin Nemutlu), İstanbul Bilgi Üniversitesi Yayınları, İstanbul.

İNSEL, Ahmet (2000), "Özgürlük Etiği Karşısında İktisat Kuramı: Amartya Sen'in Etik İktisat Önerisi", Toplum Bilim Dergisi, S.86, ss.7-21.

KETE, Nazmiye (2009), "Türk Yazılı Basınında Yoksulluk Söylemi: Yeni Kapitalizme Eleştirel Bir Bakış”, Yayımlanmamış Doktora Tezi, Ege Üniversitesi Sosyal Bilimler Enstitüsü, İzmir.

KURTARAN, Yörük, NEMUTLU, Gülesin ve YENTÜRK, Nurhan (2008). "Gençler Hakkında, Gençlik Için, Gençlerle”, Türkiye'de Gençlik Çalışması ve Politikaları (Der. Nurhan Yentürk, Yörük Kurtaran, Gülesin Nemutlu), İstanbul Bilgi Üniversitesi Yayınları, İstanbul, ss.3-19.

LEBLANC-ESPARZA, Ricardo ve ROULSTON, William S. (2012), Breaking The Poverty Barrier, Solution Tree Press, Bloomington.

MARSHALL, Gordon (1999), Sosyoloji Sözlüğü (Çev. Osman Akınhay ve Derya Kömürcü), Bilim ve Sanat Yayınları, Ankara. 
MAYRİNG, Philipp (2011), Nitel Sosyal Araştırmaya Giriş (Çev. Adnan Gümüş ve M. Sezai Durgun), Bilgesu Yayıncılık, Ankara.

METIN, Banu (2014), "Yoksullukla Mücadeleye Insan Hakları Açısından Bakmak: Amartya Sen'in Kapasite (Capability) Yaklaşımı Temelinde Bir Değerlendirme", Journal of Yaşar University, S.9(36), ss.62616380.

NEUMAN, W. Lawrence (2017), Toplumsal Araştırma Yöntemleri, Nitel ve Nicel Yaklaşımlar (Çev. Sedef Özge), Yayınodası Yayıncılık, Ankara, C.1.

OSMANI, Siddiqur Rahman (2005), "Poverty and Human Rights: Building on the Capability Approach", Journal of Human Development, S. 2, ss.205-2019.

ROBERT, Jean ve RAHNEMA, Macit (2011), Yoksulların Gücü (Çev. Şule Ünsaldı), Türkiye ve Ortadoğu Forumu Vakfı Özgür Üniversite Kitaplığı, İstanbul.

SAM, Neslihan (2008), "Yoksulluğa Bir Yaklaşım Biçimi:Kapasite Yaklaşımı", Uludağ Üniversitesi İktisadi ve İdari Bilimler Fakültesi Dergisi, S.1, ss.59-70.

SEN, Amartya (1983), "Poor, Relatively Speaking", Oxford Economic Papers, New Series, S.2, ss.153-169.

SEN, Amartya, (1989), "Development as Capability Expansion", Journal of Development Planning, S.19, ss. 41-58.

SEN, Amartya (2004a), Özgürlükle Kalkınma (Çev. Yavuz Alagon), Ayrıntı Yayınları, İstanbul.

SEN, Amartya (2004b), "Elements of a Theory of Human Rights", Philosophy and Public Affairs, S.4, ss.315356.

SWARTZ, David (2011), Kültür ve İktidar, Pierre Bourdieu'nün Sosyolojisi (Çev. Elçin Gen), İletişim Yayınları, İstanbul.

UNDP (1997), Human Development Report 1997, Oxford University Press, New York.

\section{EK-1 DERINLEMESINE GÖRÜŞME SORULARI ${ }^{*}$}

\section{Giriş, Öğrencilerin Sosyo-Ekonomik Koșulları}

1. Kendinizi kısaca tanıtır mısınız? (Adınız soyadınız. Kaç yaşındasınız? Hangi fakültede, hangi bölümde, kaçıncı sınıfta okuyorsunuz?, vb.)

2. Sosyo-ekonomik bağlamda ailenizden bahseder misiniz? (Anne- babanız, yaşları, çalışma durumları, gelirleri, mülkiyetleri? Eğitim durumları? ailenin diğer bireyleri?, vb.)

3. Öğrencilik yaşamınızda sosyo-ekonomik olarak hangi koşullar içinde yaşıyorsunuz? (Aylık ne kadar geliriniz var. Aileniz ne kadar gönderiyor? Burs allyorsanız ne kadar ve hangi kurumdan? Nerede kalıyorsunuz, devlet yurdu, özel yurt, kiralık ev, ailenizin yanında ya da kendi evinizde mi?)

4. Çalışıyor musunuz? İş yaşamınızdan bahseder misiniz? Ne kadar kazanıyorsunuz? Çalışma saatleriniz?, vb.

5. Geliriniz toplumsal hayata katılımınız için yeterli mi? (Barınma, yiyecek, giyecek, yol gibi ihtiyaçlar dışında sosyal ve kültürel anlamda ne tür ihtiyaçlarınız var ve geliriniz bunları karşılamaya yetiyor mu?)

6. Sizce, bir öğrencinin asgari düzeyde geçinmesi için ne kadar gelire ihtiyacı var?

\section{Genç Olmak, Yaşam Biçimi}

7. Bir gününüz, bir haftanız nasıl geçiyor?

8. Kültürel yaşamınızdan bahseder misiniz? Ne okur, ne dinler, ne izlersiniz?

9. Afyon'da yaşamak hakkında neler söyleyebilirsiniz? Şehir öğrencilerin ekonomik, toplumsal, kültürel yaşamına ne tür imkânlar sunuyor?

\footnotetext{
* Çalışmada kullanılan sorulardan sadece 7. ve 8. sorular kaynakçada belirtilmiş olan Özlem Avcı'nın 2012 yılında, İstanbul'da Dindar Üniversite Gençliği İki Dünya Arasında adıyla İletişim Yayınları'ndan çıkmış olan çalışmanın araştırma sorularından alınmıştır.
} 
10. Nasıl bir kişilik yapınız var? Biraz duygusal durumunuzdan, davranışsal özelliklerinizden bahsedebilir misiniz? ( Neşeli, karamsar, dişadönük, içedönük, çekingen, sinirli, hayat dolu, sakin, hareketli, vb)

11. Kendinizi ifade edebiliyor musunuz? (Kişisel yaşamınızda, ailenizde, eğitim/iş yaşamında, toplumda?)

12. Bir üniversite öğrencisi ve bir genç olarak ne tür sorunlar yaşıyorsunuz?

13. Okuduğunuz üniversitenin sizi hayata hazırlama düzeyini nasıl buluyorsunuz?

14. Yaşadığınız sorunları çözmede yetersiz kaldığınızda başvurabileceğiniz kişi, kurum ya da kuruluşlar var $\mathrm{mi}$ ?

15. Kendinize nasıl bir hayat kurmayı düşünüyorsunuz, geleceğe ilişkin hayalleriniz neler?

16. Bu toplumda genç biri olarak değer gördüğünüzü düşünüyor musunuz?

17. Toplumun gençlere bakışı ve davranışı nasıll?

\section{Yoksulluk, Yoksulluk Türleri, Yoksulluk Deneyimleri, Yoksulluk Algısı, Zenginlik Algısı}

18. Size göre yoksulluk ne anlama geliyor? Yoksul olmak ne demek?

19. Öğrencilerin hayatına ilişkin varsa kendinizden ya da diğer öğrencilerden gözlemlediğiniz yoksulluk deneyimlerinden bahsedebilir misiniz?

20. Yoksunluk duygusu yaşıyor musunuz? Nelerden yoksun olduğunuzu hissediyorsunuz?

21. Koşullarınızı diğer öğrencilerle kıyasladığınızda nasıl görüyorsunuz?

22. Sizden daha iyi koşullara (ve kötü koşullara) sahip biri sizde hangi duyguları uyandırıyor?

23. Yoksul olmak kendinizi gerçekleştirmenizde ne tür dezavantajlara neden oluyor?

24. Yoksulluktan kaynaklanan yetersizlikler, engellenmişlikler olabilir mi?

25. Bu konuda bireysel ve toplumsal olarak neler yapılabilir?

26. Yakın çevreniz ve karşılaştığınız çevrelerde yoksulluk nasıl algılanıyor?

27. Zenginlik hakkında neler söyleyebilirsiniz.

\section{Farkındalıklar, Öneriler, Çözümler}

28. Yoksulluğun nedenleri hakkında düşünür müsünüz? Yoksulluk neden kaynaklanıyor?

29. Öğrencilerin yoksulluğu konusunda devlet, sivil toplum kuruluşları, öğrenciler ne tür çözümler üretebilir?

30. Bu konuda başka önerileriniz var mı? 